\title{
Integrin $\alpha 3$ Is Required for Late Postnatal Stability of Dendrite Arbors, Dendritic Spines and Synapses, and Mouse Behavior
}

\author{
Meghan E. Kerrisk, ${ }^{1}$ Charles A. Greer, ${ }^{2,3,4}$ and Anthony J. Koleske ${ }^{1,2,4,5}$ \\ Departments of ${ }^{1}$ Molecular Biophysics and Biochemistry, ${ }^{2}$ Neurobiology, and ${ }^{3}$ Neurosurgery, and ${ }^{4}$ Interdepartmental Neuroscience Program, Yale \\ University, New Haven, Connecticut 06520, and ${ }^{5}$ Program in Cellular Neuroscience, Neurodegeneration, and Repair, Yale University, New Haven, \\ Connecticut 06536
}

\begin{abstract}
Most dendrite branches and a large fraction of dendritic spines in the adult rodent forebrain are stable for extended periods of time. Destabilization of these structures compromises brain function and is a major contributing factor to psychiatric and neurodegenerative diseases. Integrins are a class of transmembrane extracellular matrix receptors that function as $\alpha \beta$ heterodimers and activate signaling cascades regulating the actin cytoskeleton. Here we identify integrin $\alpha 3$ as a key mediator of neuronal stability. Dendrites, dendritic spines, and synapses develop normally in mice with selective loss of integrin $\alpha 3$ in excitatory forebrain neurons, reaching their mature sizes and densities through postnatal day 21 (P21). However, by P42, integrin $\alpha 3$ mutant mice exhibit significant reductions in hippocampal dendrite arbor size and complexity, loss of dendritic spine and synapse densities, and impairments in hippocampal-dependent behavior. Furthermore, gene-dosage experiments demonstrate that integrin $\alpha 3$ interacts functionally with the Arg nonreceptor tyrosine kinase to activate p190RhoGAP, which inhibits RhoA GTPase and regulates hippocampal dendrite and synapse stability and mouse behavior. Together, our data support a fundamental role for integrin $\alpha 3$ in regulating dendrite arbor stability, synapse maintenance, and proper hippocampal function. In addition, these results provide a biochemical and structural explanation for the defects in long-term potentiation, learning, and memory reported previously in mice lacking integrin $\alpha 3$.
\end{abstract}

\section{Introduction}

In the developing brain, dendrite branches and dendritic spines turn over dynamically as neurons refine connections and integrate into circuits (Dailey and Smith, 1996; Wong and Wong, 2000; Ethell and Pasquale, 2005). In stark contrast, in adulthood, most dendrite branches and many dendritic spines are stable for extended periods (Wu et al., 1999; Trachtenberg et al., 2002; Holtmaat et al., 2005, 2006). This stability is essential for proper brain function. In humans, loss of neuronal stability is a major contributing factor to the pathology of psychiatric and neurodegenerative disorders (Makris et al., 2008; Lin and Koleske, 2010; Penzes et al., 2011; Kulkarni and Firestein, 2012). Work over the past decade has revealed that long-term dendrite and dendritic

Received Feb. 4, 2013; revised March 4, 2013; accepted March 5, 2013.

Author contributions: M.E.K., C.A.G., and A.J.K. designed research; M.E.K. and A.J.K. performed research; C.A.G. contributed unpublished reagents/analytic tools; M.E.K. and A.J.K. analyzed data; M.E.K. and A.J.K. wrote the paper.

This work was supported by Public Health Service Grants NS39475 and GM100041 (A.J.K.) and National Institute on Deafness and Other Communication Disorders Grants DC00210 and DC012441 (C.A.G.). We thank J. A. Kreidberg and R. O. Hynes for generously providing mouse lines used in these studies, C. Kaliszewski and X. Ye for expert technical assistance, S. L. Gourley for advice on behavioral experiments and statistical analysis, M. S. Warren for advice on biochemical experiments, M. H. Omar for assistance on dendrite structural studies, B. J. Rosenberg for purifying antibodies, T. D. Pollard and S. S. Chandra for critical discussions on experiments, and A. D. Levy, Y. C. Lin, M. H. Omar, and M. S. Warren for careful reading and editing of this manuscript.

The authors declare no competing financial interests.

Correspondence should be addressed to Anthony J. Koleske, Department of Molecular Biophysics and Biochemistry, Yale University, 333 Cedar Street, SHM CE-31, New Haven, CT 06520. E-mail: anthony.koleske@yale.edu.

DOI:10.1523/JNEUROSCI.0528-13.2013

Copyright $\odot 2013$ the authors $\quad 0270-6474 / 13 / 336742-11 \$ 15.00 / 0$ spine stability requires the activity of intracellular signaling pathways that are triggered by extracellular cues acting on cell-surface receptors (Gorski et al., 2003; Moresco et al., 2005; Sfakianos et al., 2007; Chen et al., 2011; Warren et al., 2012). Elucidating these signaling mechanisms will lead to a deeper understanding of how neuronal stability is achieved and how its disruption contributes to destabilization in human brain diseases.

Integrins are a class of 18 heterodimeric $\alpha \beta$ receptors that adhere to the extracellular matrix (ECM) and regulate cytoskeletal-signaling pathways (DeMali et al., 2003; Dansie and Ethell, 2011). Integrins are prominently expressed in neurons (Pinkstaff et al., 1999) where they regulate neuronal migration (Gupton and Gertler, 2010), synaptic maturation (Chavis and Westbrook, 2001; Webb et al., 2007), plasticity (Chan et al., 2003; Shi and Ethell, 2006), and neuronal stability (Warren et al., 2012). In particular, integrin $\beta 1$ signals via the Arg (Abl-related gene; Abl2) nonreceptor tyrosine kinase to regulate synapse and dendrite stability. The integrin $\beta 1$ cytoplasmic tail binds directly to Arg and promotes Arg-dependent phosphorylation of the RhoA GTPase inhibitor p190RhoGAP (p190). Phosphorylation drives p190 into a complex at the membrane with p120RasGAP (p120) to inhibit RhoA, a major antagonist of dendrite stability (Nakayama et al., 2000; Hernández et al., 2004; Bradley et al., 2006; Warren et al., 2012).

These data strongly suggest that an unknown ligand for integrin $\beta 1$-Arg signaling confers dendrite and synapse stability. Integrin $\alpha$-subunits determine receptor ligand specificity (Hughes and Pfaff, 1998; Hynes, 2002; Luo et al., 2007), but the $\alpha$-subunit 
that partners with integrin $\beta 1$ to regulate the Arg-p190 pathway is unknown. We show here for the first time that integrin $\alpha 3$ is critical for the stabilization of neuronal structure in the postnatal mouse hippocampus. Loss of integrin $\alpha 3$ from excitatory neurons causes reduced hippocampal dendritic spine and synapse densities and reduced dendrite arbor complexity in adult mice. These structural deficits correlate with a pronounced impairment in a hippocampal-dependent novel object recognition task. Using biochemical and genetic strategies, we demonstrate that Arg interacts functionally with integrin $\alpha 3$ to regulate neuronal structure, mouse behavior, and p190-RhoA signaling. Together, these results identify integrin $\alpha 3$ as a key mediator of dendrite arbor, dendritic spine, and synapse stabilization.

\section{Materials and Methods}

Animal use. Mice used for these studies were of a mixed genetic background: $\arg$ (Koleske et al., 1998), germ-line itg $\alpha 3$ (Kreidberg et al., 1996), germ-line itg $\alpha 5$ (Yang et al., 1993), and NEX-Cre (Goebbels et al., 2006) mice were of C57BL/ $6 \times 129 /$ SvJ background; floxed itg $\alpha 3$ mice were of C57BL/ 6 × CD-1 × 129/SvJ background (Kim et al., 2009; Liu et al., 2009). Animal genotypes were determined using a PCR reaction, and genotypes were confirmed at death. To control for potential strain background and sex differences, we used male littermates for all experiments at postnatal day 42 (P42) (range, P42-P56). At P21 (range, P20-P22), both female and male littermates were used. Experiments comparing different genotypes and ages were conducted and scored by a single experimenter blinded to both parameters. For behavioral experiments, mice were handled 5 min each for $5 \mathrm{~d}$ before the experiment to habituate them to the tester. For experiments requiring heavy sedation, animals were administered Nembutal via intraperitoneal injection before the experiment. All procedures were compliant with federal regulations and approved by the Yale University Animal Care and Use Committee.

Genetic strategy. Mice used for conditional ablation studies were bred by crossing mice with a conditional "floxed" allele of the gene itg $\alpha 3$ (Kim et al., 2009; Liu et al., 2009) with NEX-Cre transgenic mice expressing Cre recombinase (Goebbels et al., 2006). This strategy inactivates integrin $\alpha 3$ in excitatory neurons of the hippocampus and cortex starting at embryonic day 11.5 (Goebbels et al., 2006). For simplicity, conditional integrin $\alpha 3$ knock-out mice are referred to as $N E X-\alpha 3^{-/-}$mice throughout text. Mice used for dose-sensitive genetic interaction studies were bred by crossing mice with a germ-line integrin $\alpha 3$ knock-out allele $(\alpha 3)$ (Kreidberg et al., 1996) with mice with a germ-line arg knock-out allele ( $\mathrm{arg}$ ) (Koleske et al., 1998), referred to as $\mathrm{arg}^{+/-} \alpha 3^{+/-}$mice throughout text. Dose-sensitive genetic interactions are commonly used to assess the physiological relevance in vivo of demonstrated protein interactions (Moresco et al., 2005; Sfakianos et al., 2007; Phillips, 2008; Warren et al., 2012). In this approach, reducing the gene dosage of two interacting proteins by creating a double heterozygous animal can produce a synthetic phenotype that is not present in either of the single heterozygote mutants, often mirroring the knock-out phenotype of the genes.

Synaptic fractionation. Mouse forebrain homogenates were fractionated via sucrose gradient following previously published protocols (Jones and Matus, 1974) with modifications (Biederer et al., 2002). Briefly, the cortex and hippocampus were dissected from three to six mice under deep Nembutal sedation and mechanically homogenized using a glassTeflon homogenizer in $320 \mathrm{~mm}$ sucrose with 10 mM HEPES, pH 7.4, phosphatase, and protease inhibitors. Samples were spun for $10 \mathrm{~min}$ at $800 \times g$ to clear non-homogenized tissue, and an aliquot of the supernatant was taken as the crude sample. Next, the supernatant was spun for 15 min at $10,000 \times g$ twice, resuspending the pellet each time to wash. A sample of the resulting pellet was collected as the synaptoneurosome fraction. The rest of the pellet fraction was hypotonically lysed with icecold water and centrifuged for $20 \mathrm{~min}$ at $24,000 \times g$ to fractionate synaptosomal membranes. Synaptosomal membranes were further fractionated via a stepwise sucrose gradient to obtain a final synaptic plasma membrane fraction. All purification steps were performed at $4^{\circ} \mathrm{C}$ and with ice-cold buffers. Samples were immunoblotted after
SDS-PAGE with antibodies to integrin $\alpha 3$ (clone $42 / C D 49$ c at $0.5 \mu \mathrm{g} / \mathrm{ml}$; BD Biosciences) and postsynaptic density-95 (PSD95) (clone K28/43 at $0.1 \mu \mathrm{g} / \mathrm{ml}$; University of California, Davis/National Institutes of Health NeuroMab Facility) and detected using chemiluminescence. Bands on scanned film were quantified using Quantity software to determine fold differences between genotypes (Bio-Rad Laboratories).

Electron microscopy and morphometric analyses of hippocampal synapses. Mice were anesthetized with Nembutal and transcardially perfused for $1 \mathrm{~min}$ with $\mathrm{PBS}$ plus heparin at $\mathrm{pH} 7.4$, followed by perfusion of $10 \mathrm{ml}$ of $4 \%$ paraformaldehyde $/ 2 \%$ glutaraldehyde in PBS, pH 7.4. Brains were postfixed at $4^{\circ} \mathrm{C}$ for at least $24 \mathrm{~h}$ before cutting on a vibratome. Sections were then processed in $1 \% \mathrm{OsO}_{4}$ at $4^{\circ} \mathrm{C}$ for $1 \mathrm{~h}$ (Schikorski and Stevens, 1997). Next, slices were dehydrated for $1 \mathrm{~h}$ in ethanol and stained with $0.5 \%$ uranyl acetate in 95\% ethanol. Tissue was embedded in Epon and further sliced to $70 \mathrm{~nm}$ for electron microscopy analysis. Tissue was imaged using a JEOL 100 CX II electron microscope at 12,000 $\times$ magnification. Excitatory synapses were identified and enumerated only if they contained a mushroom-shaped spine with an electron-dense PSD apposed to a presynaptic compartment containing synaptic vesicles as described in previous reports (Harris and Stevens, 1989; Sfakianos et al., 2007; Warren et al., 2012). A single experimenter made all measurements using NIH ImageJ software blinded to genotype and age. Additional sections that were not processed for electron microscopy were stained with anti-NeuN to assess overall structure as described previously (Moresco et al., 2005).

Biocytin injection and morphometric analysis of hippocampal neurons. Experiments were performed as described previously (Sfakianos et al., 2007; Warren et al., 2012). Briefly, hippocampal slices $(400 \mu \mathrm{m})$ were maintained in an interface chamber at $33^{\circ} \mathrm{C}$. Individual CA1 pyramidal neurons were injected using $300 \mathrm{~ms}$ current of $5 \mathrm{nA}$ at $1 \mathrm{~Hz}$ for $20 \mathrm{~min}$ with $4 \%$ biocytin in $2 \mathrm{~m}$ sodium acetate at $\mathrm{pH} 7.5$. Slices were fixed with $4 \%$ paraformaldehyde in PBS at $\mathrm{pH} 7.4$ for $48 \mathrm{~h}$ and cryoprotected in $30 \%$ sucrose. Tissue was then resectioned to $40 \mu \mathrm{m}$ and stained using avidin-horseradish peroxidase staining (Vectastain Elite ABC; Vector Laboratories). Neurons were traced under $100 \times$ magnification with a light microscope outfitted with a $Z$-drive and reconstructed using Neurolucida software (MicroBrightField) by an experimenter blind to the genotype and age. NeuroExplorer software (MicroBrightField) was used to calculate total dendrite length and branch-point numbers, which were further analyzed by calculating both apical and basal dendrite length and branch-point numbers independently. NeuroExplorer was also used to perform Sholl analysis on reconstructed neurons.

Dendritic spine analyses. Wild-type (WT) control and mutant littermates expressing the GFP-M1 transgene (Feng et al., 2000) were transcardially perfused for $1 \mathrm{~min}$ with PBS plus heparin at $\mathrm{pH} 7.4$, followed by perfusion of $10 \mathrm{ml}$ of $4 \%$ paraformaldehyde in PBS, and brains were postfixed for at least $24 \mathrm{~h}$. Vibratome-cut sections $(50 \mu \mathrm{m})$ were imaged on a spinning-disc UltraVIEW VoX (PerkinElmer Life and Analytical Sciences) confocal microscope under $60 \times$ magnification. Spines were analyzed and processed using Volocity (PerkinElmer Life and Analytical Sciences) software. Collapsed $z$-stack images were exported from Volocity and counted using NIH ImageJ software by a single experimenter blinded to genotype and age of each slide. Representative images were reconstructed using Volocity software "Fast Restoration" function.

Immunoprecipitations. Homogenization and immunoprecipitation were performed in ice-cold lysis buffer $(20 \mathrm{~mm}$ Tris, $\mathrm{pH} 7.5,150 \mathrm{~mm}$ $\mathrm{NaCl}, 2$ mm EDTA, and $1 \%$ Triton X-100 with protease and phosphatase inhibitors) as described previously (Warren et al., 2012). Briefly, hippocampi were dissected in ice-cold PBS, homogenized, spun to remove debris, snap frozen in liquid nitrogen, and stored at $-80^{\circ} \mathrm{C}$ until assay. Protein extract $(0.5 \mathrm{mg})$ standardized to $1 \mathrm{mg} / \mathrm{ml}$ was precleared at $4^{\circ} \mathrm{C}$ for 20 min with $40 \mu \mathrm{l}$ of protein A/G agarose beads (Calbiochem). Supernatants were then incubated with $2 \mu \mathrm{g}$ of anti-p190 antibody (clone D2D6; Millipore) at $4^{\circ} \mathrm{C}$ overnight $(12 \mathrm{~h})$ with gentle rotation, and immune complexes were bound to protein $\mathrm{A} / \mathrm{G}$ agarose beads at $4^{\circ} \mathrm{C}$ for $1 \mathrm{~h}$ with gentle rotation. Beads were washed three times with $1 \mathrm{ml}$ of lysis buffer and resuspended in $40 \mu$ l of SDS-PAGE running buffer. Samples were boiled for $10 \mathrm{~min}$ and separated via SDS-PAGE. Proteins were detected by immunoblot with anti-phospho-tyrosine (clone $4 \mathrm{G} 10$ at 0.25 
$\mu \mathrm{g} / \mathrm{ml}$ ), anti-190RhoGAP (clone DG-20 at $2 \mu \mathrm{g} / \mathrm{ml}$; Sigma), and antip120RasGAP (clone B4F8 at $1 \mu \mathrm{g} / \mathrm{ml}$; Thermo Fisher Scientific). Bands were quantified using densitometry software from ImageQuant, and relative levels of coimmunoprecipitated protein were standardized to WT littermate controls run on the same blot.

RhoA activity assays. Assays were performed on hippocampal lysate with an ELISA-based kit (Cytoskeleton) as described previously (Bradley et al., 2006).

Novel object recognition task. Mice at $\mathrm{P} 42$ were habituated to handling for $5 \mathrm{~d}$ before the experiment for $5 \mathrm{~min} / \mathrm{d}$ per mouse. Behavior was performed in a quiet room separate from housing as described previously (Sfakianos et al., 2007). Briefly, mice were habituated to a large testing cage for $1 \mathrm{~h}$. Then mice were allowed to explore two identical objects placed on either side of the testing cage for a total accumulation of $30 \mathrm{~s}$ exploration time, defined as nasal or oral contact with the objects. After $48 \mathrm{~h}$, mice were placed back in testing cage with one familiar object explored previously and one novel object and were allowed to accumulate 30 total seconds of exploration time. Mice that did not accumulate $30 \mathrm{~s}$ of exploration within $5 \mathrm{~min}$ on day 1 or day 3 were excluded from analysis. An experimenter blinded to genotype scored each session live, and in addition all sessions were recorded on video.

Statistics. All data are reported as \pm SEM with the exception of the two plots for dendritic spine cross-sectional head area, which are graphed as whisker-barrel plots, with the centerline representing mean, box edges representing \pm SEM, and outer lines representing minimum-maximum. Comparisons between WT and NEX- $\alpha 3^{-/-}$, and WT and $\mathrm{arg}^{-/-}$mice were analyzed using one-way ANOVAs and post hoc two-tailed Student's $t$ tests. Analysis of datasets from epistasis experiments with multiple genotypes was done using two-way ANOVAs to determine whether $\arg$ and itg $\alpha 3$ had a significant interaction, and, if so, post hoc two-tailed Student's $t$ tests were performed between groups. For Sholl analysis, two-way ANOVAs were performed between shell radius and genotype, followed by post hoc two-tailed Student's $t$ tests. Datasets for dendritic spine head cross-sectional area were additionally analyzed using two-tailed $F$ tests for variance. WT and littermate experimental lysates for the RhoA activity assays were run simultaneously, and each experimental sample was normalized back to its WT littermate. Data collected from these assays were analyzed using a one-sample $t$ test comparing mean of experimental reading back to $100 \%$. Novel object recognition data were analyzed using two-way ANOVAs (object $\times$ genotype) or three-way ANOVAs (object $\times$ arg $\times$ integrin), followed by post hoc two-tailed Student's $t$ tests between objects. Data from all experiments were analyzed and graphed using Prism software (GraphPad Software).

\section{Results \\ Integrin $\alpha 3$ is enriched in synaptic membranes and controls dendrite arbor size and dendritic spine density in hippocampal neurons}

Integrin $\beta 1$ is present at dendritic spines (Mortillo et al., 2012), where it is required for hippocampal dendrite and synapse stability (Warren et al., 2012). However, the $\alpha$-subunit(s) that pairs with integrin $\beta 1$ in this function is unknown. Integrins $\alpha 3, \alpha 5$, and $\alpha 8$ are all expressed in the hippocampus where they contribute to hippocampal long-term potentiation (LTP) and working memory in mice (Einheber et al., 1996; Pinkstaff et al., 1999; Bi et al., 2001; Kramár et al., 2002; Chan et al., 2003, 2007). In particular, the reduction or loss of integrin $\alpha 3$ impairs synaptic plasticity, spatial learning, and LTP (Kramár et al., 2002; Chan et al., $2003,2007)$. We found that integrin $\alpha 3$ was enriched 2.5 -fold in synaptic plasma membrane relative to crude homogenate (Fig. $1 A)$. These results are consistent with previous work showing an enrichment of integrin $\alpha 3$ levels in synaptic fractions (Kramár et al., 2002; Chan et al., 2003).

We inactivated integrin $\alpha 3$ in excitatory neurons of the forebrain starting at embryonic day 11.5 by crossing mice with a conditional floxed allele of the gene itg $\alpha 3$ (Kim et al., 2009; Liu et al., 2009) with NEX-Cre transgenic mice expressing Cre recom-

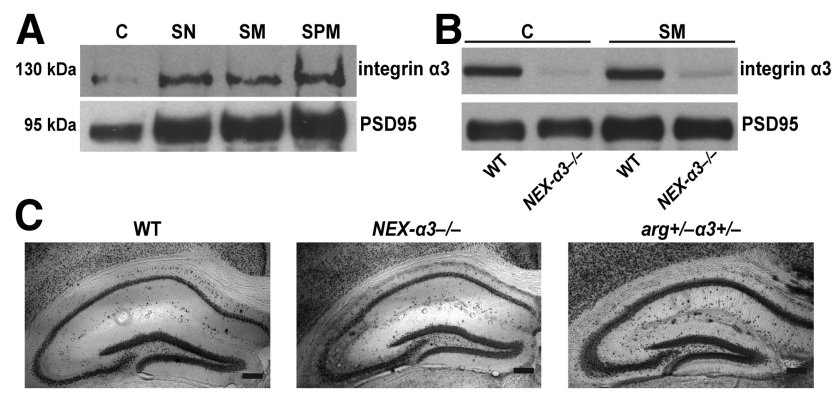

Figure 1. Integrin $\alpha 3$ is enriched at the synaptic plasma membrane (SPM), and its genetic loss does not disrupt overall hippocampal structure. $\boldsymbol{A}$, Immunoblot of a synaptic fractionation from P42 WT mouse forebrain demonstrating that integrin $\alpha 3$ is enriched at the SPM fraction relative to crude homogenate (C), synaptoneurosome (SN), and synaptic membrane (SM) fractions. PSD95 is used as fractionation control for enrichment of SPM-associated proteins. $\boldsymbol{B}$, Immunoblot of $C$ and SM fractions reveals a significant reduction of integrin $\alpha 3$ expression in NEX $-\alpha 3^{-/-}$forebrain compared with WT at P42. C, Immunohistochemistry staining using NeuN on P42 hippocampal sections shows grossly normal hippocampal structure in WT, NEX$\alpha 3^{-/-}$, and $\arg ^{+/-} \alpha 3^{+/-}$mice. Scale bar, $200 \mu \mathrm{m}$.

binase (Goebbels et al., 2006). For simplicity, conditional integrin $\alpha 3$ knock-out mice will be referred to as $N E X-\alpha 3^{-1-}$ mice. Using this genetic strategy, we found a robust elimination of integrin $\alpha 3$ protein expression in both the crude homogenate and synaptic membrane fractions from P42 mice (Fig. 1B). Because NEX-Cre is expressed only in excitatory neurons, the near complete loss of integrin $\alpha 3$ in $N E X-\alpha 3^{-/-}$mice indicates that integrin $\alpha 3$ is expressed primarily in excitatory neurons, consistent with previous reports (Kramár et al., 2002; Chan et al., 2003). At P21 NEX $-\alpha 3^{---}$mice were indistinguishable from WT littermates (weight: WT, $10.6 \pm 0.6 \mathrm{~g} ; \mathrm{NEX}-\alpha 3^{-/-}, 11.4 \pm 0.5 \mathrm{~g}$, Student's $t$ test, $p=0.3560$ ), whereas at $\mathrm{P} 42, N E X-\alpha 3^{-/-}$mice were slightly smaller than WT mice (weight: WT, $27.1 \pm 0.9 \mathrm{~g}$; $N E X-\alpha 3^{-/-}, 21.6 \pm 1.4 \mathrm{~g}$, Student's $t$ test, $p=0.0031$ ). Gross hippocampal structure in NEX $-\alpha 3^{-/-}$mice was similar to WT at both ages, as visualized by NeuN staining (Fig. 1C).

We performed reconstructions of dye-filled neurons to study how loss of integrin $\alpha 3$ affected dendrite arbor length and branching pattern (Fig. 2A). Quantitative analyses revealed that hippocampal CA1 pyramidal neurons of $\mathrm{P} 42 \mathrm{NEX}-\alpha 3^{-/-}$mice had significant reductions in dendrite arbors compared with their WT littermates, with $25 \%$ shorter total dendrite lengths and $30 \%$ fewer total branch points (length: WT, $4945.8 \pm 484.4 \mu \mathrm{m}$; $N E X-\alpha 3^{-/-}, 3727.2 \pm 223.2 \mu \mathrm{m}$, Student's $t$ test, $p=0.00013$; branches: WT, $38.8 \pm 2.3$ nodes; $N E X-\alpha 3^{-/-}, 27.3 \pm 1.7$ nodes, Student's $t$ test, $p=0.00021)$. We further analyzed these reductions by quantifying the magnitude of loss on the apical and basal dendrites independently. Apical dendrite length in $N E X-\alpha 3^{-/-}$ neurons was reduced by $20 \%$ at P42 compared with WT dendrites, and these smaller apical dendrite arbors had $17 \%$ fewer dendrite branches (Fig. $2 B, C$ ), reductions that are similar in magnitude to those observed in $\mathrm{arg}^{-1-}$ (Sfakianos et al., 2007) and $N E X-\beta 1^{-/-}$(Warren et al., 2012) mice at this age. Interestingly, $N E X-\alpha 3^{-/-}$neurons also exhibited a $31 \%$ decrease in basal dendrite length and a $43 \%$ reduction in basal dendrite branch points compared with WT littermates at P42 (Fig. 2B,C). Although $\mathrm{arg}^{-1-}$ animals did not exhibit reductions in basal dendrite arbors at P42 (Sfakianos et al., 2007), by 4 months of age, $\mathrm{arg}^{-1-}$ basal dendrites were 36\% shorter than WT littermates (Fig. 2E). Sholl analysis revealed that the dendrite reductions measured in $N E X-\alpha 3^{-\prime-}$ mice were distributed throughout the entire dendrite arbor (Fig. 2D) (Sholl, 1953). Importantly, den- 


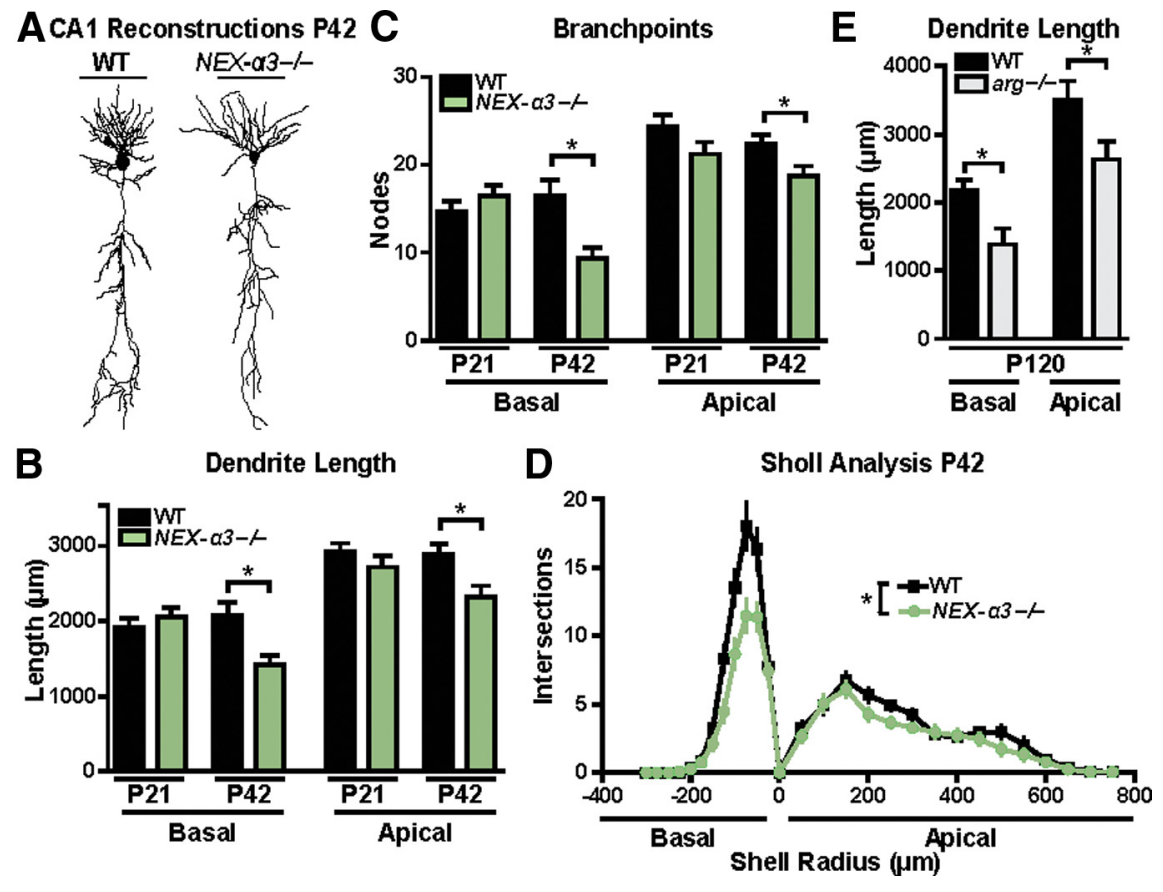

Figure 2. Hippocampal dendritic arbors develop normally in NEX- $\alpha 3^{-/-}$mice but are reduced by P42. $\boldsymbol{A}$, Representative Neurolucida dendrite reconstructions of WT and NEX- $\alpha 3^{-1-}$ hippocampal CA1 pyramidal neurons at P42. B, C, Mean total dendrite length $(\boldsymbol{B})$ and branch-point number $(\boldsymbol{C})$ of basal (left) and apical (right) dendrites of hippocampal CA1 pyramidal neurons. Dendrite length and branch points of both basal and apical arbors in NEX- $\alpha 3^{-1-}$ neurons are reduced at P42 compared with WT littermates. There are no differences between WT and NEX $-\alpha 3^{-1-}$ neurons at P21 in any of the measured morphological parameters. ANOVA between groups: basal length, $F=5.018, p=0.0028$; apical length, $F=4.034, p=0.0098$; basal branch points, $F=6.101, p=0.0008$; apical branch points, $F=3.827, p=0.0128$. Post hoc Student's $t$ test: basal length, $p=0.4317$ for $\mathrm{P} 21, p=0.0057$ for $\mathrm{P} 42$; apical length, $p=0.2804$ for $\mathrm{P} 21, p=0.0104$ for $\mathrm{P} 42$; basal branch points, $p=0.3186$ for $\mathrm{P} 21, p=$ 0.0019 for P42; apical branch points, $p=0.1144$ for P21, $p=0.0232$ for P42. $n=19-31$ neurons from 11-15 mice for each group. $D$, Sholl analysis of WT and NEX- $\alpha 3^{-1-}$ neurons at P42 to measure dendrite complexity from the same neurons reconstructed above demonstrates a reduction in NEX- $\alpha 3^{-1-}$ neurons throughout the entire dendrite arbor. Two-way ANOVA (shell radius $\times$ genotype): interaction, $F=4.589, p<0.0001$; effect of genotype, $F=43.63, p<0.0001$; effect of shell radius, $F=$ $43.63, p<0.0001$. E, Mean total dendrite length of basal (left) and apical (right) hippocampal CA1 pyramidal neurons is reduced in $\mathrm{arg}^{-1-}$ mice at 4 months compared with WT. ANOVA between groups: $F=12.87, p<0.0001$. Post hoc Student's $t$ test: basal length, $p=0.017$; apical length, $p=0.0377$. Error bars indicate mean \pm SEM. ${ }^{*} p<0.05$.

drites developed normally in $N E X-\alpha 3^{-/-}$mice through P21, when they were indistinguishable in length or branch points from WT (Fig. $2 B, C$ ). Instead dendrites regressed between P21 and P42, demonstrating a role for integrin $\alpha 3$ in the stabilization, rather than development, of dendrite arbors.

The enrichment of integrin $\alpha 3$ at synaptic plasma membrane (Fig. $1 A$ ) and the decrease in PSD95 levels in NEX- $\alpha 3^{-1-}$ (Fig. $1 B$ ) suggested that integrin $\alpha 3$ might also affect dendritic spine stability. We used confocal microscopy to measure dendritic spine density on the dendrites of WT and NEX- $\alpha 3^{-/-}$CA1 pyramidal neurons that were labeled by thyl-GFP transgene expression (Fig. 3A) (Feng et al., 2000). Dendritic spine density was similar at P21 in WT and NEX- $\alpha 3^{-/-}$neurons (Fig. $3 B$ ). However, by $\mathrm{P} 42$, dendritic spine density was reduced by $11 \%$ in $N E X-\alpha 3^{-1-}$ mice (Fig. $3 B$ ). Thus, integrin $\alpha 3$ is not required for dendritic spine formation, but loss of integrin $\alpha 3$ compromises the stability of a subset of dendritic spines.

Deletion of integrin $\alpha 3$ reduces hippocampal synapse density and impairs behavioral tasks

The finding that $N E X-\alpha 3^{-/-}$mice exhibited age-dependent destabilization of dendrites and dendritic spines led us to investigate the impact of these changes on synapse density, morphology, and hippocampal function. Furthermore, PSD95 levels appeared to be reduced in the synaptic membrane fraction in $N E X-\alpha 3^{-1-}$ mice compared with WT (Fig. 1B), consistent with our findings that these mice have decreased dendritic spine density (Fig. 3B). To quantify synapses directly, we used electron microscopy to measure the density and monitor key ultrastructural parameters of Schaffer collateral-CA1 (SC-CA1) synapses that form on the apical dendrite arbors of CA1 pyramidal neurons (Fig. $3 C)$. Although we observed no differences in SC-CA1 synapse density in WT and $N E X-\alpha 3^{-/-}$mice at P21, NEX- $\alpha 3^{-/-}$ mice had a $24 \%$ reduction in synapse density by $\mathrm{P} 42$ when compared with WT littermates (Fig. 3C,D). Additionally, we measured PSD length and cross-sectional spine head area of these synapses. As we and others have reported previously (Harris et al., 1992; Sfakianos et al., 2007), we found that synapses in WT mice transitioned from highly variable spine head size at P21 to an overall smaller and more uniform head size by P42 with less variance in head size. However, NEX- $\alpha 3^{-/-}$ spine head areas did not undergo this agedependent transition to smaller more uniform dendritic spine head sizes. As a result, the average length of the PSD in $N E X-\alpha 3^{-/-}$synapses was $13 \%$ longer (Fig. $3 E$ ) and cross-sectional spine head area was $43 \%$ larger (Fig. $3 F$ ) than WT littermates at P42. This overall synapse loss and failure to transition to smaller, more uniform spine profiles in NEX$\alpha 3^{-/-}$mice closely mirrors phenotypes described previously in $\mathrm{arg}^{-/-}$mice at the same ages (Sfakianos et al., 2007).

The significant reduction in hippocampal synapse density and abnormal synaptic ultrastructure in NEX- $\alpha 3^{-/-}$mice suggested that integrin $\alpha 3$ may influence overall hippocampal function. We tested whether the loss of integrin $\alpha 3$ affected novel object recognition, a behavior known to depend on hippocampal function (Baker and Kim, 2002; Broadbent et al., 2004; Warren et al., 2012), as well as other brain regions (Winters et al., 2004; McNulty et al., 2012). Adult WT, NEX- $\alpha 3^{+/-}$, and NEX- $\alpha 3^{-/-}$ mice were first habituated to the testing environment and then allowed to explore two identical objects for a total of $30 \mathrm{~s}$. During this phase of the experiment, all genotypes explored the objects for equivalent amounts of time (WT: right, $14.5 \pm 0.9 \mathrm{~s}$; left, $15.5 \pm 0.9 \mathrm{~s} ; N E X-\alpha 3^{+/-}$: right, $14.9 \pm 1.3 \mathrm{~s}$; left, $15.1 \pm 0.9 \mathrm{~s} ;$ $N E X-\alpha 3^{-/-}$: right, $16.0 \pm 0.9 \mathrm{~s}$; left, $14.0 \pm 1.7 \mathrm{~s}$ ). Mice were then returned to their home cage and after $48 \mathrm{~h}$ were tested with one of the previously explored objects and a novel object. Although WT and NEX- $\alpha 3^{+/-}$mice spent significantly more time with the novel object during this phase, $N E X-\alpha 3^{-1-}$ mice spent equal time exploring both objects (Fig. $3 G$ ). Similar defects in novel object recognition have been reported previously in mice whose neurons were deficient in Arg (Sfakianos et al., 2007) and integrin $\beta 1$ (Warren et al., 2012) and in mice with lesions to the hippocampus (Baker and Kim, 2002; Broadbent et al., 2004). 
Integrin $\alpha 3$ interacts functionally with Arg kinase to regulate p190 and RhoA activity

p190 is a major substrate of Arg in neurons in which it inactivates RhoA GTPase to regulate dendrite arbor size (Hernández et al., 2004; Sfakianos et al., 2007; Warren et al., 2012). Integrin $\beta 1$ signaling through Arg promotes phosphorylation of p190 and its binding to p120, which recruits the complex to the membrane to attenuate RhoA activity (Parsons, 1996; Arthur et al., 2000; Hernández et al., 2004; Bradley et al., 2006; Peacock et al., 2007; Sfakianos et al., 2007; Warren et al., 2012). To determine whether the loss of integrin $\alpha 3$ compromises Arg-p190 signaling, we immunoprecipitated p190 from hippocampal lysates of NEX- $\alpha 3^{-1-}$ and WT littermates at P21 and P42 and measured p190 phosphorylation (pY-p190) and the relative amount of p120 bound to p190 (p120/p190) as a readout of p190 activity (Fig. 4A) (Hernández et al., 2004; Bradley et al., 2006; Sfakianos et al., 2007; Warren et al., 2012). Although the relative pYp190 and p120/p190 levels did not differ between $N E X-\alpha 3^{-1-}$ and WT mice at $\mathrm{P} 21, N E X-\alpha 3^{-/-}$mice had a $13 \%$ reduction in pY-p190 (Fig. 4C) and a 21\% reduction in p120/p190 at P42 (Fig. 4D). It should be noted that hippocampal glia also express high levels of p190 and p120, and p190 is phosphorylated via a distinct Fyn-dependent pathway in these cells (Wolf et al., 2001; Liang et al., 2004). NEX-Cre-mediated inactivation of integrin $\alpha 3$ does not affect the glial pool of p190, which likely accounts for the significant residual active $\mathrm{p} 190$ in $N E X-\alpha 3^{-/-}$

hippocampal extracts. Decreased p190 signaling enhances RhoA activity (Nakayama et al., 2000; Sfakianos et al., 2007). Indeed, we found that RhoA activity was unchanged between WT and NEX$\alpha 3^{-/-}$hippocampal lysates at P21 but increased by $26 \%$ in NEX$\alpha 3^{-/-}$mice at P42 (Fig. 4E), coincident with the age-dependent reduction in p190 signaling.

We next used dose-sensitive genetic interactions (Moresco et al., 2005; Sfakianos et al., 2007; Phillips, 2008; Warren et al., 2012) to test whether integrin $\alpha 3$ interacts functionally with Arg to control p190 activity. For these experiments, we used a germ-line integrin $\alpha 3$ knock-out allele $(\alpha 3)$ (Kreidberg et al., 1996). arg $^{+/-} \alpha 3^{+/-}$mice were indistinguishable from WT littermates and had normal overall hippocampal structure as visualized by $\mathrm{NeuN}$ staining (Fig. 1C). Integrin $\alpha 3$ protein levels from $\alpha 3^{+/-}$and $\arg ^{+/-} \alpha 3^{+/-}$mice and Arg protein levels from $\mathrm{arg}^{+/-}$and $\mathrm{arg}^{+/-} \alpha 3^{+/-}$mice were reduced by $\sim 50 \%$ compared with WT in synaptic fractions (data not shown). p190 phosphorylation and p120/p190 levels in WT, $\mathrm{arg}^{+/-}$, and $\alpha 3^{+/-}$ hippocampal lysates were unchanged at $\mathrm{P} 42$, whereas $\mathrm{arg}^{+1}$ $-\alpha 3^{+/-}$lysates exhibited a $21 \%$ decrease in pY-p190 (Fig. $4 C$ ) and a 35\% decrease in p120/p190 (Fig. 4D), accompanied by a $32 \%$ increase in RhoA activity (Fig. $4 E$ ). The decreases in pYp190 and p120/p190 and increased RhoA activity closely resemble the timing and magnitude of these reductions measured in NEX-

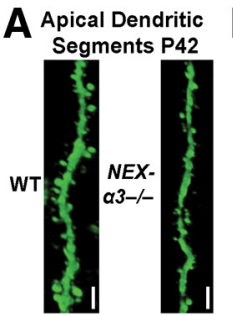
mean \pm SEM. ${ }^{*} p<0.05$.
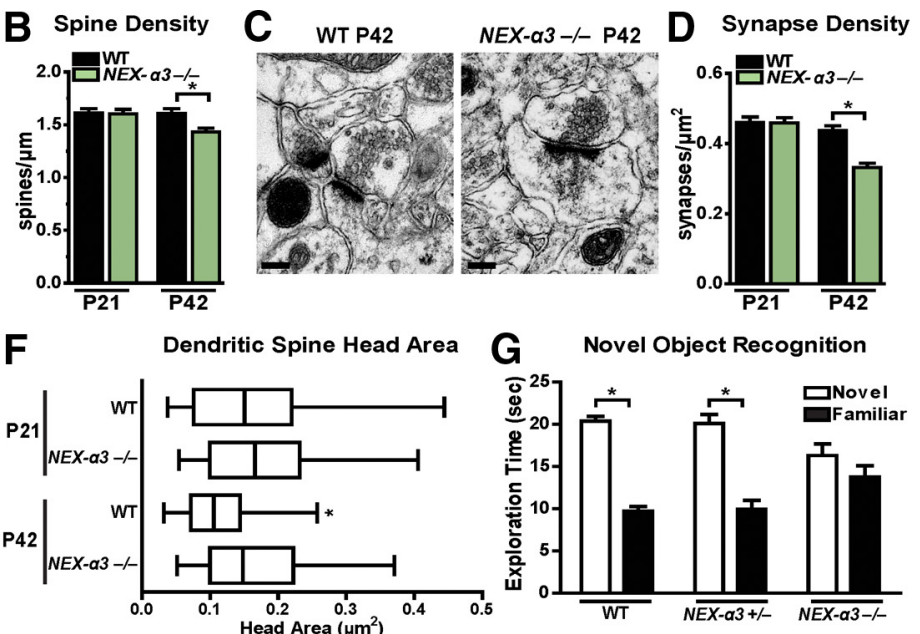

Figure 3. $N E X-\alpha 3^{-/-}$mice have reduced hippocampal SC-CA1 synapse density, altered synaptic ultrastructure, and impair-

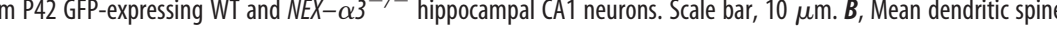
$p=0.0032$. Post hoc Student's $t$ test: $p=0.8334$ for P21, $p=0.0031$ for P42. $n=33-50$ neurons from 5 mice per group. 21.26, $p<0.0001$. Post hoc Student's $t$ test: $p=0.9451$ for P21, $p<0.0001$ for P42. $n=46-54$ sections from 3-4 mice $p e$ group. $\boldsymbol{E}$, Mean PSD length is increased in NEX- $\alpha 3^{-1-}$ synapses compared with WT littermates at P42. At P21, NEX- $\alpha 3^{-/-}$ pared with WT littermates. Two-way ANOVA (age $\times$ genotype): interaction, $F=3.912, p=0.0488$; effect of genotype, $F=$ 0.0008; effect of age, $F=9.297, p=0.0025$. Post hoc Student's $t$ test: $p=0.3893$ for P21; $p<0.0001$ for P42

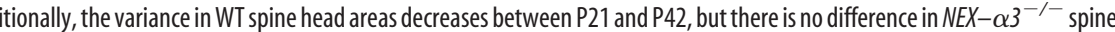

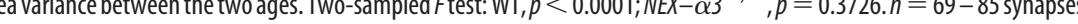
mice spend equal time exploring the novel object and familiar object from day 1 (black bar). Tw0-way ANOVA 作 WT, $p<0.0001, n=6$ mice; NEX $-\alpha 3^{+/-}, p=0.0005, n=5$ mice; NEX- $\alpha 3^{-/-}, p=0.2192, n=6$ mice. Error bars indicate

$\alpha 3^{-/-}$(Fig. 4), $\mathrm{arg}^{-/-}$(Sfakianos et al., 2007), or NEX- $\beta 1^{-/-}$ (Warren et al., 2012) mice. Together, these findings support a model in which integrin $\alpha 3 \beta 1$ acts upstream of Arg and p190 to regulate RhoA activity in the mouse hippocampus.

\section{Integrin $\alpha 3$ interacts functionally with Arg to regulate} synapse and dendrite maintenance and behavior Our finding that integrin $\alpha 3$ and Arg interact functionally to regulate p190 signaling raised the question of whether this interaction also impacts neuronal stability and animal behavior. We found that hippocampal CA1 neurons in WT, $\mathrm{arg}^{+/-}, \alpha 3^{+/-}$, and $\mathrm{arg}^{+/-} \alpha 3^{+/-}$mice have apical arbors that are indistinguishable in all morphological parameters measured at P21 (Fig. 5A-C). However, $\mathrm{arg}^{+/-} \alpha 3^{+/-}$mice had $15 \%$ shorter apical dendrites (Fig. $5 B$ ) and $22 \%$ fewer branch points (Fig. 5C) compared with age-matched WT, $\mathrm{arg}^{+/-}$, and $\alpha 3^{+/-}$littermates. Sholl analysis revealed that the loss of dendrites in $\mathrm{arg}^{+/-} \alpha 3^{+/-}$neurons occurred throughout the entire apical arbor, but basal arbors were not significantly affected (Fig. 5D). Importantly, mice double heterozygous for Arg and integrin $\alpha 5$ (Yang et al., 1993) $\left(\mathrm{arg}^{+/}\right.$ $-\alpha 5^{+/-}$) did not exhibit deficits in hippocampal dendrite arbor morphology (Fig. 5B,C), indicating that this interaction was specific to integrin $\alpha 3$. The age dependence of this apical dendrite 

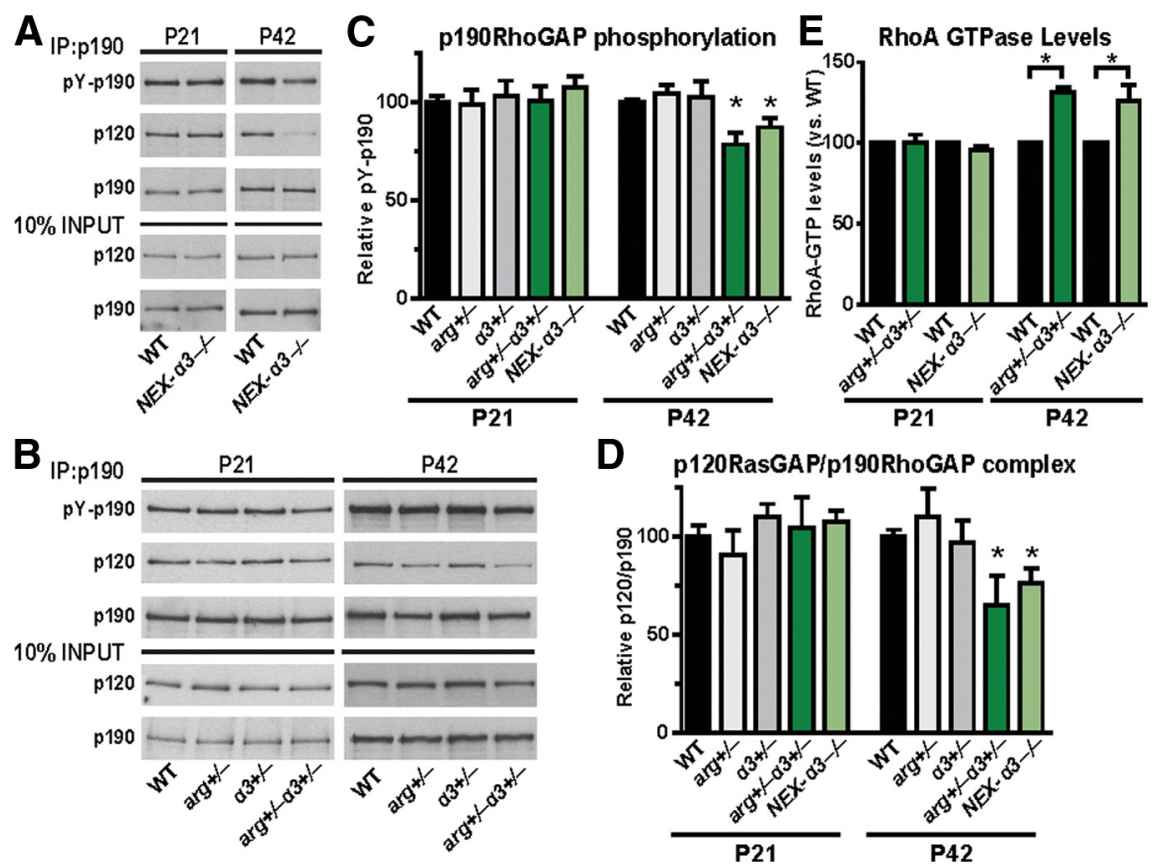

Figure 4. Integrin $\alpha 3$ signals through Arg kinase to regulate $p 190$ and RhoA activity. $A, B$, Representative immunoblots from immunoprecipitations (IP) of p190 from hippocampal lysates of WT and NEX $-\alpha 3^{-/-}$littermates $(\boldsymbol{A})$ and WT, $\arg ^{+/-}, \alpha 3^{+/-}$, and arg $^{+/-} \alpha 3^{+/-}$littermates $(\boldsymbol{B})$ showing pY-p190 levels, comimmunoprecipitated p120 levels, and 10\% input controls at P21 and P42. C, Quantification of pY-p190 levels of WT and mutant hippocampal lysates at P21 and P42. $\arg ^{+/-} \alpha 3^{+/-}$and NEX$\alpha 3^{-/-}$p190 phosphorylation was reduced compared with WT, $\arg ^{+/-}$, and $\alpha 3^{+/-}$littermates at P42 but was unaffected at P21. Two-way ANOVA of P21 $(\arg \times \alpha 3)$ : no interaction, $F=0.0058$. Two-way ANOVA of P42 $(\arg \times \alpha 3)$ : interaction, $F=9.702$, $p=0.0032$; main effect of $\alpha 3, F=6.676, p=0.0132$. Post hoc Student's $t$ test: WT, $p<0.0001 ; \mathrm{arg}^{+/-}, p=0.0036 ; \alpha 3^{+/-}$, $p=0.0352$. ANOVA (WT and NEX- $\alpha 3^{-1-}$ ): $F=3.586, p=0.0271$. Post hoc Student'st test: P21, $p=0.3009 ; \mathrm{P} 42, p=0.0467$. $n=8-19$ mice per genotype. $\boldsymbol{D}$, Quantification of p120/p190 complex levels of WT and mutant hippocampal lysates at P21 and P42. $\mathrm{arg}^{+/-} \alpha 3^{+/-}$and NEX- $\alpha 3^{-/-}$p120/p190 complex levels were reduced compared with WT, $\arg ^{+/-}$, and $\alpha 3^{+/-}$ littermates at $\mathrm{P} 42$ but were unaffected at P21. Two-way ANOVA of P21 (arg $\times \alpha 3$ ): no interaction, $F=0.0257$. Two-way ANOVA of P42 ( $\arg \times \alpha 3$ ): interaction, $F=4.161, p=0.048$; main effect of $\alpha 3, F=5.426, p=0.025$. Posthoc Student's $t$ test: WT, $p=$ $0.0077 ; \arg ^{+/-}, p=0.0485 ; \alpha 3^{+/-}, p=0.0108$. ANOVA (WT and NEX- $\left.\alpha 3^{-/-}\right): F=2.796, p=0.0179$. Post hoc Student's $t$ test: P21, $p=0.9705 ; \mathrm{P} 42, p=0.0248 . n=6-17$ mice per genotype. $E$, Quantification of RhoA activity of arg $^{+/-} \alpha 3^{+/-}$and $N E X-\alpha 3^{-/-}$hippocampal lysate compared with a WT littermate control run in same assay. Both $\arg ^{+/-} \alpha 3^{+/-}$and NEX$\alpha 3^{-/-}$mice had elevated levels of active hippocampal RhoA at P42 but not at P21. One-sample $t$ test compared means with 100 : P21 $\mathrm{arg}^{+/-} \alpha 3^{+/-}, p=0.9522 ; \mathrm{P} 42 \mathrm{arg}^{+/-} \alpha 3^{+/-}, p=0.0079 ; \mathrm{P} 21$ NEX $-\alpha 3^{-/-}, p=0.1986 ; N E X-\alpha 3^{-/-}, p=0.0308$. $n=3-8$ mice per group. Error bars indicate mean \pm SEM. ${ }^{*} p<0.05$.

regression corresponds exactly with that observed previously in neurons lacking integrin $\alpha 3$ (Fig. $2 A-C$ ), Arg (Sfakianos et al., 2007), and integrin $\beta 1$ (Warren et al., 2012). These data strongly support a role for integrin $\alpha 3 \beta 1$ signaling through Arg in stabilizing hippocampal dendrite arbors.

Additionally, we find CA1 pyramidal neuron dendritic spine density was decreased by $7 \%$ in $\arg ^{+/-} \alpha 3^{+/-}$mice at P42 compared with WT, $\arg ^{+/-}$, and $\alpha 3^{+/-}$neurons, whereas no differences were detected at P21 (Fig. $5 E, F$ ). Similarly, synapse density measured by electron microscopy was normal in $\mathrm{arg}^{+/-} \alpha 3^{+/-}$mice at P21, but reduced $17 \%$ compared with WT at P42 (Fig. 6A,B). Measurements of synaptic ultrastructure of synapses remaining at $\mathrm{P} 42 \mathrm{arg}^{+/-} \alpha 3^{+/-}$ mice revealed 18\% longer PSDs (Fig. 6C), 28\% larger cross-sectional dendritic spine head area, and significantly larger variance in head area (Fig. 6D). Again these changes were similar to those observed previously in mice with compromised integrin $\beta 1$-Arg-p190 signaling (Sfakianos et al., 2007; Gourley et al., 2012; Warren et al., 2012).

We also tested the ability of $\mathrm{arg}^{+/-} \alpha 3^{+/-}$and control mice to discriminate between a novel and a familiar object. On day 1, all genotypes explored the objects for equivalent amounts of time (WT: right, $16.5 \pm 0.9 \mathrm{~s}$; left, $13.5 \pm 0.9 \mathrm{~s} ; \mathrm{arg}^{+/-}$: right, $17.9 \pm$ $1.5 \mathrm{~s} ;$ left, $12.1 \pm 1.5 \mathrm{~s} ; \alpha 3^{+/-}$: right, $17.7 \pm 1.1 \mathrm{~s} ;$ left, $12.3 \pm 1.1 \mathrm{~s}$; $\arg ^{+/-} \alpha 3^{+/-}$: right, $15.6 \pm 1.1 \mathrm{~s} ;$ left, $14.4 \pm 1.1 \mathrm{~s} ; \alpha 5^{+/-}$: right, $15.9 \pm 0.9 \mathrm{~s}$; left, $14.1 \pm 0.9 \mathrm{~s} ; \mathrm{arg}^{+/-} \alpha 5^{+/-}$: right, $16.3 \pm 1.9 \mathrm{~s}$; left, $13.7 \pm 1.9 \mathrm{~s})$. Similar to $N E X-\alpha 3^{-/-}$mice (Fig. 3G), at P42, arg $^{+/}$ $-\alpha 3^{+/-}$mice failed to discriminate between the novel and familiar objects, whereas WT, $\mathrm{arg}^{+/-}$, and $\alpha 3^{+/-}$mice displayed a preference for the novel object on day 3 (Fig. 6E). The same defect was observed in mice lacking either Arg (Sfakianos et al., 2007) or integrin $\beta 1$ (Warren et al., 2012). Moreover, novel object recognition was normal in $\alpha 5^{+/-}$ and $\mathrm{arg}^{+/-} \alpha 5^{+/-}$mice (Fig. 6E), further indicating a specific interaction between integrin $\alpha 3$ and Arg in regulating this behavior. Together, these data strongly support the hypothesis that integrin $\alpha 3 \beta 1$ signals through Arg to control hippocampal dendrite stability, synapse morphology and maintenance, and overall hippocampal function (Fig. 7).

\section{Discussion}

The loss of dendrite arbor and dendritic spine stability in humans is a major contributing factor to the pathology of psychiatric illnesses and neurodegenerative diseases (Lin and Koleske, 2010; Kulkarni and Firestein, 2012). Uncovering the mechanisms that confer dendrite and spine stability is an essential first step toward understanding how they become compromised in human disease and for developing treatment strategies. We report here, for the first time, that integrin $\alpha 3$ acts to stabilize dendrites, dendritic spines, and synapses. Loss of integrin $\alpha 3$ function leads to significant atrophy of dendrite arbors and loss of dendritic spines, disrupts maturation of the remaining synapses, and compromises overall hippocampal function. Moreover, we demonstrate that integrin $\alpha 3$ acts upstream of an Arg-p190 RhoA inhibitory pathway that is a critical regulator of dendrite stability. Together, these results identify and characterize integrin $\alpha 3$ as an essential regulator of dendrite arbor and dendritic spine stability in the postnatal brain.

Dysregulation of integrin $\alpha 3-$ Arg signaling may contribute to neuronal stabilization defects in humans

Defects in dendrite arbor size and complexity, dendritic spine density, and synaptic connectivity are associated with several pathological conditions, including schizophrenia, (Glantz and Lewis, 2000; Kalus et al., 2000; Law et al., 2004), depression (Cotter et al., 2001; Duman and Aghajanian, 2012), and intellectual disability (Kaufmann and Moser, 2000; Kaufmann et al., 2000; Ramakers, 2000). Mutations in genes encoding proteins in the integrin $\alpha 3 \beta 1-$ Arg signaling axis have been linked to human disorders in brain development. For example, chromosomal microdeletions involving integrin $\alpha 3$ and duplications of integrin $\alpha 3$ coding regions have been found in patients with intellectual disability (Zahir et al., 2009; Preiksaitiene et al., 2012). Likewise, 

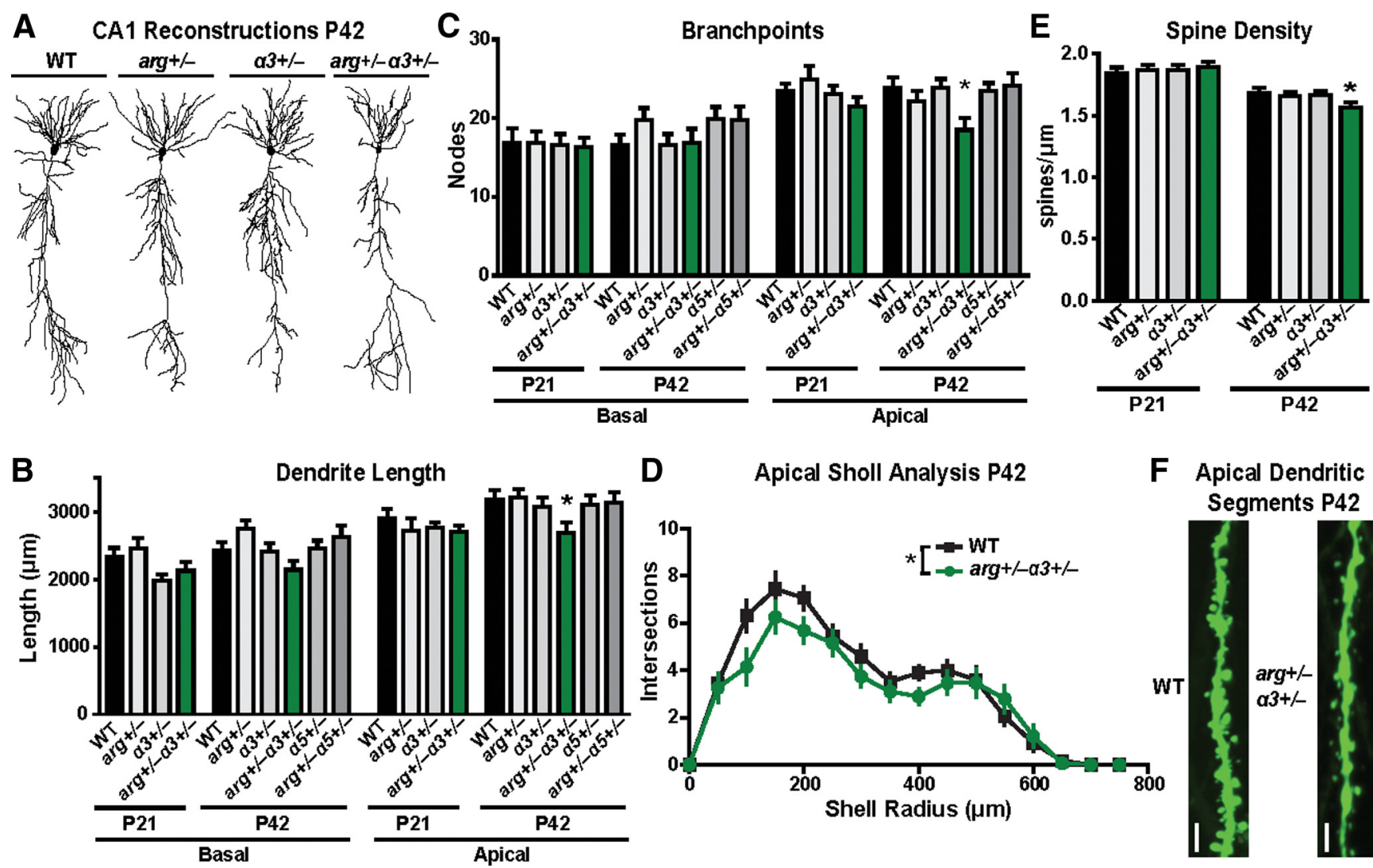

D Apical Sholl Analysis P42

F Apical Dendritic

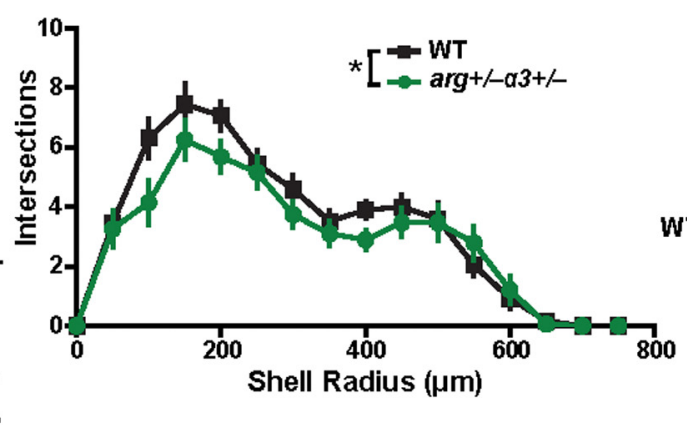
Segments P42

Figure 5. Integrin $\alpha 3$ and Arg kinase functionally interact to regulate the maintenance of hippocampal apical dendrite length and spines. $\boldsymbol{A}$, Representative Neurolucida dendrite reconstructions of WT, $\arg ^{+/-}, \alpha 3^{+/-}$, and $\arg ^{+/-} \alpha 3^{+/-}$hippocampal CA1 pyramidal neurons at P42. B, C, Mean total dendrite length (B) and branch-point number (C) of basal (left) and apical (right) dendrites on hippocampal CA1 pyramidal neurons. Apical dendrite length and branch points of $\arg ^{+/-} \alpha 3^{+/-}$mice are reduced at P42 compared with WT littermates. ANOVA between groups at P21: basal length, $F=2.482, p=0.0664$; apical length, $F=1.820, p=0.1305 ;$ basal branch points, $F=0.0364, p=0.9906$; apical branch points, $F=1.196, p=0.3164$. ANOVA between groups at P42: basal length, $F=2.409, p=0.0531$; apical length, $F=2.985, p=0.0354$; basal branch points, $F=1.209, p=0.3106 ;$ apical branch points, $F=3.088, p=0.0314$. Post hoc Student's $t$ test apical length: WT, $p=0.0193 ; \arg ^{+/-}, p=0.0105 ; \alpha 3^{+/-}, p=0.0403$. Post hoc Student's $t$ test apical branch points: WT, $p=0.0149 ;$ arg $^{+/-}, p=0.0410 ; \alpha 3^{+/-}, p=0.0077 . n=$ 27-31 neurons from 14-19 mice for each group. $D$, Sholl analysis of WT and $a r g^{+/-} \alpha 3^{+/-}$neurons at P42 to measure dendrite complexity from the same reconstructions demonstrates a reduction in $\mathrm{arg}^{+/-} \alpha 3^{+/-}$neurons throughout apical dendrite arbor only. Two-way ANOVA (apical shell radius $\times$genotype): interaction, $F=1.574, p=0.049 ;$ effect of genotype, $F=5.47, p=$ 0.023; effect of shell radius, $F=48.54, p<0.0001$. $E$, Mean dendritic spine density is reduced in $\arg ^{+/-} \alpha 3^{+/-}$mice at P42 compared with WT littermates. ANOVA between groups: $F=2.697$, $p=0.047$. Post hoc Student's $t$ test: $p=0.0336 . n=38-50$ neurons from 5 mice per group. $F$, Representative reconstructions from confocal $z$-stacks of apical dendrite segments from P42 GFP-expressing WT and $\arg ^{+/-} \alpha 3^{+/-}$hippocampal CA1 neurons. Scale bar, $10 \mu \mathrm{m}$. Error bars indicate mean \pm SEM. ${ }^{*} p<0.05$.

microdeletions involving genes for integrin $\beta 1$ (Megarbane et al., 2001; Talkowski et al., 2012), Arg (Scarbrough et al., 1988; Takano et al., 1997; Chaabouni et al., 2006), p190 (James et al., 1996; Leal et al., 2009), and Rho-family GTPases (Newey et al., 2005; Benarroch, 2007) have all been identified in cases of intellectual disability that have been associated with developmental disorders. Mice with mutations in key components of this pathway exhibit defects in dendrite stability and dendritic spine density and morphology that resemble those observed in neurodevelopmental disorders and also exhibit widespread defects in learning, memory, and behavioral flexibility as presented here and in previous studies (Sfakianos et al., 2007; Gourley et al., 2009, 2012; Warren et al., 2012). Continued investigation of these signaling components will reveal whether they are also disrupted in psychiatric and neurodegenerative diseases and, if so, whether they can be targeted therapeutically to stabilize neuronal structure to ameliorate disease.

Synaptic plasticity, ultrastructure, and maintenance are disrupted in integrin $\alpha 3$ mutant mice

Integrin $\alpha 3$ is expressed broadly throughout the rodent brain, including hippocampal pyramidal neurons (Pinkstaff et al.,
1999), and integrin $\alpha 3$ is particularly enriched in synaptic fractionations (Fig. 1A) (Kramár et al., 2002; Chan et al., 2003). Previously, it was found that integrin $\alpha 3$ plays an essential role in NMDA receptor-dependent LTP, spatial learning, and working memory (Kramár et al., 2002; Chan et al., 2003, 2007). Our results identify biochemical and structural mechanisms that may underline the role of integrin $\alpha 3$ in these processes. Interestingly, mice with postnatal excitatory neuron-specific ablation of integrin $\alpha 3$ ( $\alpha$-CaMKII-Cre) have been reported previously to exhibit normal ultrastructure of SC-CA1 hippocampal synapses (Chan et al., 2007). We found that $N E X-\alpha 3^{-/-}$synapses have disrupted ultrastructure at P42, resulting in increased synaptic head area and increased PSD length, likely attributable to failure to undergo characteristic morphological changes (Harris et al., 1992; Sfakianos et al., 2007). One possible explanation for these differences is the time course of Cre-mediated inactivation of integrin $\alpha 3$ via the two transgenes: NEX-Cre expression begins at embryonic day 11.5 (Goebbels et al., 2006), whereas $\alpha$-CaMKII-Cre expression is initiated at P25 (Tsien et al., 1996). This suggests that integrin $\alpha 3$ may be required between E11.5 and P25 to perform some function required for later stabilization of neuronal structure. However, integrin $\alpha 3$ protein levels were not directly 
A WT P42
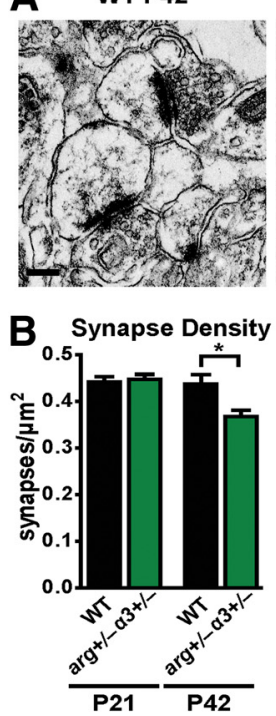

$\arg +/-a 3+/-$ P42
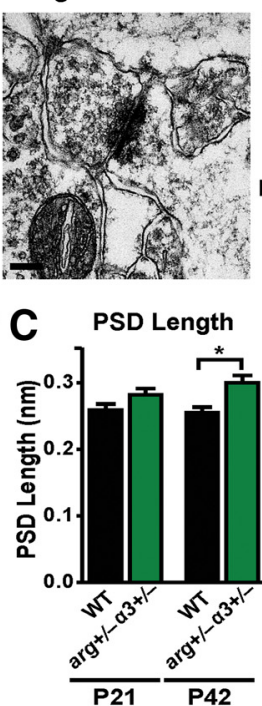

D

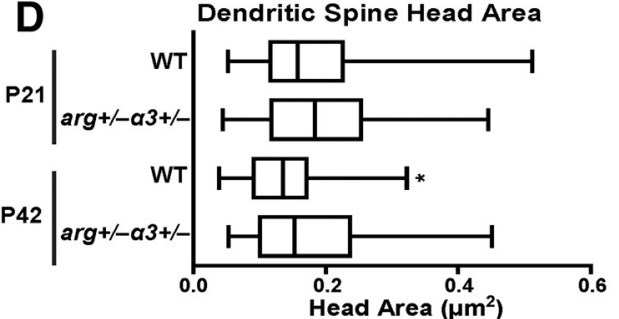

E
Novel Object Recognition

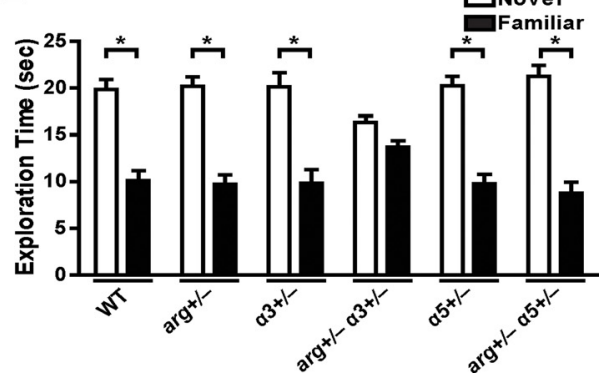

Figure 6. $\arg ^{+/-} \alpha 3^{+/-}$mice have decreased synapse density, disrupted synaptic ultrastructure, and abnormal behavior. $\boldsymbol{A}$, Representative electron micrographs of hippocampal SC-CA1 synapses from P42 WT and arg ${ }^{+/-} \alpha 3^{+/-}$mice. Scale bar, $200 \mathrm{~nm}$. $\boldsymbol{B}$, Mean synapse density is reduced in $\arg ^{+/-} \alpha 3^{+/-}$mice compared with WT littermates at P42 but not P21. ANOVA between groups: $F=8.983, p<0.0001$. Post hoc Student's test: $P 21, p=0.6427 ; P 42, p<0.0001 . n=33-52$ sections from 3- 4 mice per group. C, Mean PSD length is increased in $\arg ^{+/-} \alpha 3^{+/-}$synapses compared with WT littermates at P42. At P21, arg ${ }^{+1}$ $-\alpha 3^{+/-}$synapses have an increased PSD length compared with WT, although it was not statistically significant. ANOVA between groups: $F=5.218, p=0.0015$. Posthoc Student's test: $P 21, p=0.0689 ; P 42, p=0.0015 . n=75-112$ synapses from 3- 4 mice per group. $\boldsymbol{D}$, Mean dendritic spine cross-sectional head area fails to decrease in $\mathrm{arg}^{+/-} \alpha 3^{+/-}$synapses between P21 and P42 compared with WT littermates. ANOVA between groups: $F=6.519, p=0.0003$. Post hoc Student's $t$ test: $P 21, p=0.6215 ; P 42$, $p=0.0008$. Additionally, the variance in WT spine head areas decreases between P21 and P42, but there is no difference in $\mathrm{arg}^{+/-} \alpha 3^{+/-}$spine head area variance between the two ages. Two-sampled $F$ test: WT, $p<0.0001 ; \arg ^{+/-} \alpha 3^{+/-}, p=$ $0.7255 . n=75-112$ synapses from 3-4 mice per group. E, Performance of WT, $\arg ^{+/-}, \alpha 3^{+/-}, \arg ^{+/-} \alpha 3^{+/-}, \alpha 5^{+/-}$, and $\mathrm{arg}^{+/-} \alpha 5^{+/-}$mice in an object recognition task at P42. On day 1, exploration time of two identical objects is identical in all genotypes. Here, all genotypes show a preference for the novel object (white bar) on day 3 of testing, except $\mathrm{arg}^{+/-} \alpha 3^{+/-}$mice who spend equal time with the novel object and familiar object from day 1 (black bar). Three-way ANOVA (object $X \arg X$ integrin): $F=3.868, p=0.023$; main effect of object, $F=160.091, p<0.001$. Post hoc Student's $t$ test: WT, $p<0.0001, n=$ 22 mice; $\mathrm{arg}^{+/-}, p<0.0001, n=17$ mice; $\alpha 3^{+/-}, p<0.0001, n=11$ mice; $\arg ^{+/-} \alpha 3^{+/-}, p=0.0724, n=8$ mice; $\alpha 5^{+/-}, p<0.0001, n=9$ mice; $\arg ^{+/-} \alpha 5^{+/-}, p<0.0001, n=9$ mice. Error bars indicate mean \pm SEM. ${ }^{*} p<0.05$.

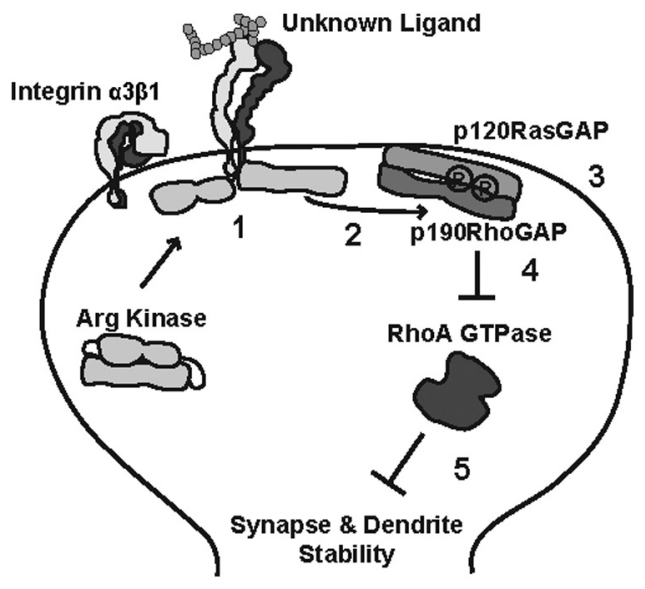

Figure 7. Model for integrin $\alpha 3 \beta 1$ signaling to Arg kinase in hippocampal dendritic spines. Integrin $\alpha 3 \beta 1$ (1) is activated by an unknown upstream extracellular ligand. The intracellular tail of $\beta 1$ binds to and activates Arg kinase, Arg phosphorylates p190 (2), phosphorylated p190 forms a complex with p120 at the postsynaptic membrane (3), and the p120/p190 complex inhibits RhoA GTPase activity (4) and promotes the stability of neuronal morphology (5).

measured in the CaMKII- $\alpha 3^{-1-}$ mice. Thus, it is also possible that CaMKII-Cre-mediated recombination does not eliminate integrin $\alpha 3$ protein as efficiently as NEX-Cre, resulting in less severe phenotypes.
Integrin $\alpha 3$ mediates the stability of apical and basal dendrite arbors $N E X-\alpha 3^{-/-}$hippocampal CA1 pyramidal neurons exhibit reduced dendrite arbor size and complexity throughout the entire dendrite tree at P42. Although similar defects have been observed in apical dendrites of $\mathrm{arg}^{-/-}$hippocampal neurons at P42 (Sfakianos et al., 2007), reductions in basal arbors occur later in these animals, starting at 4 months. The different timescales of basal arbor loss in NEX$\alpha 3^{-/-}$and $\mathrm{arg}^{-/-}$dendrites suggest that integrin $\alpha 3$ may signal via undiscovered pathways that overlap partially with Arg. The larger size of apical compared with basal dendrite arbors may make them initially more sensitive to disruption of Arg function. We also note the phenotypes in the $N E X-\beta 1^{-/-}$were less severe than those observed in $N E X-\alpha 3^{-/-}$mice. However, the inactivation of integrin $\beta 1$ in that study was less complete $(>80 \%)$ (Warren et al., 2012) than the near complete integrin $\alpha 3$ inactivation reported here.

\section{Arg-p190-RhoA signaling downstream of integrin $\alpha 3 \beta 1$}

Elevated RhoA activity in neurons causes dendrite destabilization (Threadgill et al., 1997; Ruchhoeft et al., 1999; Li et al., 2000; Nakayama et al., 2000; Sfakianos et al., 2007). We report that integrin $\alpha 3$ interacts functionally with Arg to activate p190 and inhibit RhoA activity to promote overall dendrite stability. These phenotypes are similar to those observed in the
Warren et al., 2012). Integrins function as $N E X-\beta 1^{-/-}$mice (Warren et al., 2012). Integrins function as
heterodimeric receptors and integrin $\alpha 3$ is a major binding partner for integrin $\beta 1$ (Laplantine et al., 2000; Hynes, 2002; Cox et al., 2010). Together with previous reports from our laboratory, the data presented here support the following model (Fig. 7): (1) integrin $\alpha 3 \beta 1$ binds to and activates Arg kinase (Warren et al., 2012); (2) Arg phosphorylates p190; (3) pY-p190 forms a complex with $\mathrm{p} 120$, which is recruited to the postsynaptic membrane; (4) the p120/p190 complex inhibits RhoA GTPase activity; and (5) the brake on RhoA activity promotes the stability of neuronal morphology by influencing the neuronal cytoskeleton. Additionally, we report that integrin $\alpha 3$ interacts functionally with Arg to regulate novel object recognition behavior. This behavior is dependent on hippocampal connectivity (Baker and Kim, 2002; Broadbent et al., 2004), as well as various cortical regions (Winters et al., 2004; McNulty et al., 2012).

Recently, our laboratory has used neuronal cell culture to determine that Arg kinase controls dendrite and synapse stability via distinct biochemical mechanisms. Knockdown of Arg in hippocampal neuronal cultures recapitulates the dendrite morphology and dendritic spines reductions found in vivo. Similar to $\mathrm{arg}^{-/-}$mice, inhibition of RhoA signaling in cultured knockdown neurons blocks the dendrite loss but maintains the decreased spine density. Conversely, we found that the reduction of dendritic spine density in Arg knockdown cultures was depen- 
dent on interactions between Arg and the actin-stabilizing protein cortactin (MacGrath and Koleske, 2012; Lin et al., 2013). Here, we find that loss of integrin $\alpha 3$ reduces dendrite, dendritic spine, and synapse stability, suggesting that integrin $\alpha 3 \beta 1$ is upstream of both biochemical signaling cascades.

\section{What acts upstream of integrin $\alpha 3 \beta 1$ to confer dendrite and dendritic spine stability?}

The integrin $\alpha$-subunit extracellular head domain helps determine ligand specificity (Hughes and Pfaff, 1998; Hynes, 2002; Luo et al., 2007). Therefore, our identification of integrin $\alpha 3$ as the partner for integrin $\beta 1$ in the control of neuronal stability narrows the list of candidate ligands that activate Arg signaling to promote stabilization in vivo. The ECM contains many integrin $\alpha 3 \beta 1$ ligands (Humphries et al., 2006; Dansie and Ethell, 2011), and its components are secreted from both neurons and glial cells in the brain where they influence neuronal development, structure, maintenance, plasticity, and regeneration (Dityatev and Schachner, 2006; Dityatev et al., 2010). Laminins are canonical ECM integrin ligands, and a subset of laminin chains is specific to integrin $\alpha 3 \beta 1$ (Belkin and Stepp, 2000; Nishiuchi et al., 2006). Several laminin subunit chains are expressed in the hippocampus (Chen et al., 2003; Indyk et al., 2003; Egles et al., 2007) where they influence synapse density and ultrastructure (Egles et al., 2007) and spatial learning in mice (Yang et al., 2011). Although Reelin conventionally signals through Dab1 (Dulabon et al., 2000; Niu et al., 2008) and Netrins are known to signal via Frazzled/DCC (Stanco et al., 2009; Qu et al., 2013), both proteins can also bind integrin $\alpha 3 \beta 1$ and thus are also candidates for initiating stabilization. Future studies should identify which of these potential ligands engage integrin $\alpha 3 \beta 1$ in the hippocampus and which cells_-neurons, glia, or both-are responsible for secreting it. Additionally, it will be important to understand how expression and processing of this ligand is regulated. Together, these studies will reveal what factors govern the stabilization of neuronal structure in the maturing brain and potentially lead to the development of novel strategies for therapeutic intervention for a variety of pathological conditions.

\section{References}

Arthur WT, Petch LA, Burridge K (2000) Integrin engagement suppresses RhoA activity via a c-Src-dependent mechanism. Curr Biol 10:719-722. CrossRef Medline

Baker KB, Kim JJ (2002) Effects of stress and hippocampal NMDA receptor antagonism on recognition memory in rats. Learn Mem 9:58-65. CrossRef Medline

Belkin AM, Stepp MA (2000) Integrins as receptors for laminins. Microsc Res Tech 51:280-301. CrossRef Medline

Benarroch EE (2007) Rho GTPases: role in dendrite and axonal growth, mental retardation, and axonal regeneration. Neurology 68:1315-1318. CrossRef Medline

Bi X, Lynch G, Zhou J, Gall CM (2001) Polarized distribution of alpha5 integrin in dendrites of hippocampal and cortical neurons. J Comp Neurol 435:184-193. CrossRef Medline

Biederer T, Sara Y, Mozhayeva M, Atasoy D, Liu X, Kavalali ET, Südhof TC (2002) SynCAM, a synaptic adhesion molecule that drives synapse assembly. Science 297:1525-1531. CrossRef Medline

Bradley WD, Hernández SE, Settleman J, Koleske AJ (2006) Integrin signaling through Arg activates p190RhoGAP by promoting its binding to p120RasGAP and recruitment to the membrane. Mol Biol Cell 17:48274836. CrossRef Medline

Broadbent NJ, Squire LR, Clark RE (2004) Spatial memory, recognition memory, and the hippocampus. Proc Natl Acad Sci USA 101:1451514520. CrossRef Medline

Chaabouni M, Martinovic J, Sanlaville D, Attie-Bittach T, Caillat S, Turleau C, Vekemans M, Morichon N (2006) Prenatal diagnosis and molecular characterization of an interstitial 1q24.2q25.2 deletion. Eur J Med Gen 49:487-493. CrossRef Medline

Chan CS, Weeber EJ, Kurup S, Sweatt JD, Davis RL (2003) Integrin requirement for hippocampal synaptic plasticity and spatial memory. J Neurosci 23:7107-7116. Medline

Chan CS, Levenson JM, Mukhopadhyay PS, Zong L, Bradley A, Sweatt JD, Davis RL (2007) Alpha3-integrins are required for hippocampal longterm potentiation and working memory. Learn Mem 14:606-615. CrossRef Medline

Chavis P, Westbrook G (2001) Integrins mediate functional pre- and postsynaptic maturation at a hippocampal synapse. Nature 411:317-321. CrossRef Medline

Chen AI, Nguyen CN, Copenhagen DR, Badurek S, Minichiello L, Ranscht B, Reichardt LF (2011) TrkB (tropomyosin-related kinase B) controls the assembly and maintenance of GABAergic synapses in the cerebellar cortex. J Neurosci 31:2769-2780. CrossRef Medline

Chen ZL, Indyk JA, Strickland S (2003) The hippocampal laminin matrix is dynamic and critical for neuronal survival. Mol Biol Cell 14:2665-2676. CrossRef Medline

Cotter DR, Pariante CM, Everall IP (2001) Glial cell abnormalities in major psychiatric disorders: the evidence and implications. Brain Res Bull 55: 585-595. CrossRef Medline

Cox D, Brennan M, Moran N (2010) Integrins as therapeutic targets: lessons and opportunities. Nat Rev Drug Discov 9:804-820. CrossRef Medline

Dailey ME, Smith SJ (1996) The dynamics of dendritic structure in developing hippocampal slices. J Neurosci 16:2983-2994. Medline

Dansie LE, Ethell IM (2011) Casting a net on dendritic spines: the extracellular matrix and its receptors. Dev Neurobiol 71:956-981. CrossRef Medline

DeMali KA, Wennerberg K, Burridge K (2003) Integrin signaling to the actin cytoskeleton. Curr Opin Cell Biol 15:572-582. CrossRef Medline

Dityatev A, Schachner M (2006) The extracellular matrix and synapses. Cell Tissue Res 326:647-654. CrossRef Medline

Dityatev A, Schachner M, Sonderegger P (2010) The dual role of the extracellular matrix in synaptic plasticity and homeostasis. Nat Rev Neurosci 11:735-746. CrossRef Medline

Dulabon L, Olson EC, Taglienti MG, Eisenhuth S, McGrath B, Walsh CA, Kreidberg JA, Anton ES (2000) Reelin binds alpha3betal integrin and inhibits neuronal migration. Neuron 27:33-44. CrossRef Medline

Duman RS, Aghajanian GK (2012) Synaptic dysfunction in depression: potential therapeutic targets. Science 338:68-72. CrossRef Medline

Egles C, Claudepierre T, Manglapus MK, Champliaud MF, Brunken WJ, Hunter DD (2007) Laminins containing the beta2 chain modulate the precise organization of CNS synapses. Mol Cell Neurosci 34:288-298. CrossRef Medline

Einheber S, Schnapp LM, Salzer JL, Cappiello ZB, Milner TA (1996) Regional and ultrastructural distribution of the alpha 8 integrin subunit in developing and adult rat brain suggests a role in synaptic function. J Comp Neurol 370:105-134. CrossRef Medline

Ethell IM, Pasquale EB (2005) Molecular mechanisms of dendritic spine development and remodeling. Prog Neurobiol 75:161-205. CrossRef Medline

Feng G, Mellor RH, Bernstein M, Keller-Peck C, Nguyen QT, Wallace M, Nerbonne JM, Lichtman JW, Sanes JR (2000) Imaging neuronal subsets in transgenic mice expressing multiple spectral variants of GFP. Neuron 28:41-51. CrossRef Medline

Glantz LA, Lewis DA (2000) Decreased dendritic spine density on prefrontal cortical pyramidal neurons in schizophrenia. Arch Gen Psychiatry 57:65-73. CrossRef Medline

Goebbels S, Bormuth I, Bode U, Hermanson O, Schwab MH, Nave KA (2006) Genetic targeting of principal neurons in neocortex and hippocampus of NEX-Cre mice. Genesis 44:611-621. CrossRef Medline

Gorski JA, Zeiler SR, Tamowski S, Jones KR (2003) Brain-derived neurotrophic factor is required for the maintenance of cortical dendrites. J Neurosci 23:6856-6865. Medline

Gourley SL, Koleske AJ, Taylor JR (2009) Loss of dendrite stabilization by the Abl-related gene (Arg) kinase regulates behavioral flexibility and sensitivity to cocaine. Proc Natl Acad Sci USA 106:16859-16864. CrossRef Medline

Gourley SL, Olevska A, Warren MS, Taylor JR, Koleske AJ (2012) Arg kinase regulates prefrontal dendritic spine refinement and cocaine-induced plasticity. J Neurosci 32:2314-2323. CrossRef Medline 
Gupton SL, Gertler FB (2010) Integrin signaling switches the cytoskeletal and exocytic machinery that drives neuritogenesis. Dev Cell 18:725-736. CrossRef Medline

Harris KM, Stevens JK (1989) Dendritic spines of CA 1 pyramidal cells in the rat hippocampus: serial electron microscopy with reference to their biophysical characteristics. J Neurosci 9:2982-2997. Medline

Harris KM, Jensen FE, Tsao B (1992) Three-dimensional structure of dendritic spines and synapses in rat hippocampus (CA1) at postnatal day 15 and adult ages: implications for the maturation of synaptic physiology and long-term potentiation. J Neurosci 12:2685-2705. Medline

Hernández SE, Settleman J, Koleske AJ (2004) Adhesion-dependent regulation of p190RhoGAP in the developing brain by the Abl-related gene tyrosine kinase. Curr Biol 14:691-696. CrossRef Medline

Holtmaat AJ, Trachtenberg JT, Wilbrecht L, Shepherd GM, Zhang X, Knott GW, Svoboda K (2005) Transient and persistent dendritic spines in the neocortex in vivo. Neuron 45:279-291. CrossRef Medline

Holtmaat A, Wilbrecht L, Knott GW, Welker E, Svoboda K (2006) Experience-dependent and cell-type-specific spine growth in the neocortex. Nature 441:979-983. CrossRef Medline

Hughes PE, Pfaff M (1998) Integrin affinity modulation. Trends Cell Biol 8:359-364. CrossRef Medline

Humphries JD, Byron A, Humphries MJ (2006) Integrin ligands at a glance. J Cell Sci 119:3901-3903. CrossRef Medline

Hynes RO (2002) Integrins: bidirectional, allosteric signaling machines. Cell 110:673-687. CrossRef Medline

Indyk JA, Chen ZL, Tsirka SE, Strickland S (2003) Laminin chain expression suggests that laminin-10 is a major isoform in the mouse hippocampus and is degraded by the tissue plasminogen activator/plasmin protease cascade during excitotoxic injury. Neuroscience 116:359-371. CrossRef Medline

James C, Jauch A, Robson L, Watson N, Smith A (1996) A 3 1/2 year old girl with distal trisomy 19q defined by FISH. J Med Genet 33:795-797. CrossRef Medline

Jones DH, Matus AI (1974) Isolation of synaptic plasma membrane from brain by combined flotation-sedimentation density gradient centrifugation. Biochim Biophys Acta 356:276-287. CrossRef Medline

Kalus P, Müller TJ, Zuschratter W, Senitz D (2000) The dendritic architecture of prefrontal pyramidal neurons in schizophrenic patients. Neuroreport 11:3621-3625. CrossRef Medline

Kaufmann WE, Moser HW (2000) Dendritic anomalies in disorders associated with mental retardation. Cereb Cortex 10:981-991. CrossRef Medline

Kaufmann WE, MacDonald SM, Altamura CR (2000) Dendritic cytoskeletal protein expression in mental retardation: an immunohistochemical study of the neocortex in Rett syndrome. Cereb Cortex 10:992-1004. CrossRef Medline

Kim KK, Wei Y, Szekeres C, Kugler MC, Wolters PJ, Hill ML, Frank JA, Brumwell AN, Wheeler SE, Kreidberg JA, Chapman HA (2009) Epithelial cell alpha3betal integrin links beta-catenin and Smad signaling to promote myofibroblast formation and pulmonary fibrosis. J Clin Invest 119:213-224. CrossRef Medline

Koleske AJ, Gifford AM, Scott ML, Nee M, Bronson RT, Miczek KA, Baltimore D (1998) Essential roles for the Abl and Arg tyrosine kinases in neurulation. Neuron 21:1259-1272. CrossRef Medline

Kramár EA, Bernard JA, Gall CM, Lynch G (2002) Alpha3 integrin receptors contribute to the consolidation of long-term potentiation. Neuroscience 110:29-39. CrossRef Medline

Kreidberg JA, Donovan MJ, Goldstein SL, Rennke H, Shepherd K, Jones RC, Jaenisch R (1996) Alpha 3 beta 1 integrin has a crucial role in kidney and lung organogenesis. Development 122:3537-3547. Medline

Kulkarni VA, Firestein BL (2012) The dendritic tree and brain disorders. Mol Cell Neurosci 50:10-20. CrossRef Medline

Laplantine E, Vallar L, Mann K, Kieffer N, Aumailley M (2000) Interaction between the cytodomains of the alpha 3 and beta 1 integrin subunits regulates remodelling of adhesion complexes on laminin. J Cell Sci 113: 1167-1176. Medline

Law AJ, Weickert CS, Hyde TM, Kleinman JE, Harrison PJ (2004) Reduced spinophilin but not microtubule-associated protein 2 expression in the hippocampal formation in schizophrenia and mood disorders: molecular evidence for a pathology of dendritic spines. Am J Psychiatry 161:18481855. CrossRef Medline

Leal T, Andrieux J, Duban-Bedu B, Bouquillon S, Breviere GM, Delobel B
(2009) Array-CGH detection of a de novo 0.8Mb deletion in 19q13.32 associated with mental retardation, cardiac malformation, cleft lip and palate, hearing loss and multiple dysmorphic features. Eur J Med Genet 52:62-66. CrossRef Medline

Liang X, Draghi NA, Resh MD (2004) Signaling from integrins to Fyn to Rho family GTPases regulates morphologic differentiation of oligodendrocytes. J Neurosci 24:7140-7149. CrossRef Medline

Li Z, Van Aelst L, Cline HT (2000) Rho GTPases regulate distinct aspects of dendritic arbor growth in Xenopus central neurons in vivo. Nat Neurosci 3:217-225. CrossRef Medline

Lin YC, Koleske AJ (2010) Mechanisms of synapse and dendrite maintenance and their disruption in psychiatric and neurodegenerative disorders. Annu Rev Neurosci 33:349-378. CrossRef Medline

Lin YC, Yeckel MF, Koleske AJ (2013) Abl2/Arg controls dendritic spine and dendrite arbor stability via distinct cytoskeletal control pathways. J Neurosci 33:1846-1857. CrossRef Medline

Liu Y, Chattopadhyay N, Qin S, Szekeres C, Vasylyeva T, Mahoney ZX, Taglienti M, Bates CM, Chapman HA, Miner JH, Kreidberg JA (2009) Coordinate integrin and c-Met signaling regulate Wnt gene expression during epithelial morphogenesis. Development 136:843-853. CrossRef Medline

Luo BH, Carman CV, Springer TA (2007) Structural basis of integrin regulation and signaling. Annu Rev Immunol 25:619-647. CrossRef Medline

MacGrath SM, Koleske AJ (2012) Arg/Abl2 modulates the affinity and stoichiometry of binding of cortactin to F-actin. Biochemistry 51:66446653. CrossRef Medline

Makris N, Gasic GP, Kennedy DN, Hodge SM, Kaiser JR, Lee MJ, Kim BW, Blood AJ, Evins AE, Seidman LJ, Iosifescu DV, Lee S, Baxter C, Perlis RH, Smoller JW, Fava M, Breiter HC (2008) Cortical thickness abnormalities in cocaine addiction-a reflection of both drug use and a pre-existing disposition to drug abuse? Neuron 60:174-188. CrossRef Medline

McNulty SE, Barrett RM, Vogel-Ciernia A, Malvaez M, Hernandez N, Davatolhagh MF, Matheos DP, Schiffman A, Wood MA (2012) Differential roles for $\mathrm{Nr} 4 \mathrm{a} 1$ and $\mathrm{Nr} 4 \mathrm{a} 2$ in object location vs. object recognition longterm memory. Learn Mem 19:588-592. CrossRef Medline

Megarbane A, Gosset P, Souraty N, Lapierre JM, Korban R, Zahed L, Samaras L, Vekemans M, Prieur M (2001) Chromosome 10p11.2-p12.2 duplication: report of a patient and review of the literature. Am J Med Genet 104:204-208. CrossRef Medline

Moresco EM, Donaldson S, Williamson A, Koleske AJ (2005) Integrinmediated dendrite branch maintenance requires Abelson (Abl) family kinases. J Neurosci 25:6105-6118. CrossRef Medline

Mortillo S, Elste A, Ge Y, Patil SB, Hsiao K, Huntley GW, Davis RL, Benson DL (2012) Compensatory redistribution of neuroligins and N-cadherin following deletion of synaptic beta1-integrin. J Comp Neurol 520:20412052. CrossRef Medline

Nakayama AY, Harms MB, Luo L (2000) Small GTPases Rac and Rho in the maintenance of dendritic spines and branches in hippocampal pyramidal neurons. J Neurosci 20:5329-5338. Medline

Newey SE, Velamoor V, Govek EE, Van Aelst L (2005) Rho GTPases, dendritic structure, and mental retardation. J Neurobiol 64:58-74. CrossRef Medline

Nishiuchi R, Takagi J, Hayashi M, Ido H, Yagi Y, Sanzen N, Tsuji T, Yamada M, Sekiguchi K (2006) Ligand-binding specificities of laminin-binding integrins: a comprehensive survey of laminin-integrin interactions using recombinant alpha3beta1, alpha6beta1, alpha7betal and alpha6beta4 integrins. Matrix Biol 25:189-197. CrossRef Medline

Niu S, Yabut O, D’Arcangelo G (2008) The Reelin signaling pathway promotes dendritic spine development in hippocampal neurons. J Neurosci 28:10339-10348. CrossRef Medline

Parsons JT (1996) Integrin-mediated signalling: regulation by protein tyrosine kinases and small GTP-binding proteins. Curr Opin Cell Biol 8:146-152. CrossRef Medline

Peacock JG, Miller AL, Bradley WD, Rodriguez OC, Webb DJ, Koleske AJ (2007) The Abl-related gene tyrosine kinase acts through p190RhoGAP to inhibit actomyosin contractility and regulate focal adhesion dynamics upon adhesion to fibronectin. Mol Biol Cell 18:3860-3872. CrossRef Medline

Penzes P, Cahill ME, Jones KA, VanLeeuwen JE, Woolfrey KM (2011) Dendritic spine pathology in neuropsychiatric disorders. Nat Neurosci 14: 285-293. CrossRef Medline

Phillips PC (2008) Epistasis-the essential role of gene interactions in the 
structure and evolution of genetic systems. Nat Rev Genet 9:855-867. CrossRef Medline

Pinkstaff JK, Detterich J, Lynch G, Gall C (1999) Integrin subunit gene expression is regionally differentiated in adult brain. J Neurosci 19:15411556. Medline

Preiksaitiene E, Männik K, Dirse V, Utkus A, Ciuladaite Z, Kasnauskiene J, Kurg A, Kučinskas V (2012) A novel de novo 1.8 Mb microdeletion of $17 q 21.33$ associated with intellectual disability and dysmorphic features. Eur J Med Genet 55:656-659. CrossRef Medline

Qu C, Li W, Shao Q, Dwyer T, Huang H, Yang T, Liu G (2013) c-Jun $\mathrm{N}$-terminal kinase 1 (JNK1) is required for coordination of netrin signaling in axon guidance. J Biol Chem 288:1883-1895. 10.1074/ jbc.M112.417881 Medline

Ramakers GJ (2000) Rho proteins and the cellular mechanisms of mental retardation. Am J Med Genet 94:367-371. CrossRef Medline

Ruchhoeft ML, Ohnuma S, McNeill L, Holt CE, Harris WA (1999) The neuronal architecture of Xenopus retinal ganglion cells is sculpted by rhofamily GTPases in vivo. J Neurosci 19:8454-8463. Medline

Scarbrough PR, Files B, Carroll AJ, Quinlan RW, Finley SC, Finley WH (1988) Interstitial deletion of chromosome 1 [del(1)(q25q32)] in an infant with prune belly sequence. Prenat Diagn 8:169-174. CrossRef Medline

Schikorski T, Stevens CF (1997) Quantitative ultrastructural analysis of hippocampal excitatory synapses. J Neurosci 17:5858-5867. Medline

Sfakianos MK, Eisman A, Gourley SL, Bradley WD, Scheetz AJ, Settleman J, Taylor JR, Greer CA, Williamson A, Koleske AJ (2007) Inhibition of Rho via Arg and p190RhoGAP in the postnatal mouse hippocampus regulates dendritic spine maturation, synapse and dendrite stability, and behavior. J Neurosci 27:10982-10992. CrossRef Medline

Shi Y, Ethell IM (2006) Integrins control dendritic spine plasticity in hippocampal neurons through NMDA receptor and $\mathrm{Ca}^{2+} /$ calmodulindependent protein kinase II-mediated actin reorganization. J Neurosci 26:1813-1822. CrossRef Medline

Sholl DA (1953) Dendritic organization in the neurons of the visual and motor cortices of the cat. J Anat 87:387-406. Medline

Stanco A, Szekeres C, Patel N, Rao S, Campbell K, Kreidberg JA, Polleux F, Anton ES (2009) Netrin-1-alpha3betal integrin interactions regulate the migration of interneurons through the cortical marginal zone. Proc Natl Acad Sci USA 106:7595-7600. CrossRef Medline

Takano T, Yamanouchi Y, Mori Y, Kudo S, Nakayama T, Sugiura M, Hashira S, Abe T (1997) Interstitial deletion of chromosome 1q [del(1)(q24q25.3)] identified by fluorescence in situ hybridization and gene dosage analysis of apolipoprotein A-II, coagulation factor V, and antithrombin III. Am J Med Gen 68:207-210. CrossRef Medline
Talkowski ME, Rosenfeld JA, Blumenthal I, Pillalamarri V, Chiang C, Heilbut A, Ernst C, Hanscom C, Rossin E, Lindgren AM, Pereira S, Ruderfer D, Kirby A, Ripke S, Harris DJ, Lee JH, Ha K, Kim HG, Solomon BD, Gropman AL, et al (2012) Sequencing chromosomal abnormalities reveals neurodevelopmental loci that confer risk across diagnostic boundaries. Cell 149:525-537. CrossRef Medline

Threadgill R, Bobb K, Ghosh A (1997) Regulation of dendritic growth and remodeling by Rho, Rac, and Cdc42. Neuron 19:625-634. CrossRef Medline

Trachtenberg JT, Chen BE, Knott GW, Feng G, Sanes JR, Welker E, Svoboda $\mathrm{K}$ (2002) Long-term in vivo imaging of experience-dependent synaptic plasticity in adult cortex. Nature 420:788-794. CrossRef Medline

Tsien JZ, Chen DF, Gerber D, Tom C, Mercer EH, Anderson DJ, Mayford M, Kandel ER, Tonegawa S (1996) Subregion- and cell type-restricted gene knockout in mouse brain. Cell 87:1317-1326. CrossRef Medline

Warren MS, Bradley WD, Gourley SL, Lin YC, Simpson MA, Reichardt LF, Greer CA, Taylor JR, Koleske AJ (2012) Integrin betal signals through Arg to regulate postnatal dendritic arborization, synapse density, and behavior. J Neurosci 32:2824-2834. CrossRef Medline

Webb DJ, Zhang H, Majumdar D, Horwitz AF (2007) alpha5 integrin signaling regulates the formation of spines and synapses in hippocampal neurons. J Biol Chem 282:6929-6935. CrossRef Medline

Winters BD, Forwood SE, Cowell RA, Saksida LM, Bussey TJ (2004) Double dissociation between the effects of peri-postrhinal cortex and hippocampal lesions on tests of object recognition and spatial memory: heterogeneity of function within the temporal lobe. J Neurosci 24:5901-5908. CrossRef Medline

Wolf RM, Wilkes JJ, Chao MV, Resh MD (2001) Tyrosine phosphorylation of p190 RhoGAP by Fyn regulates oligodendrocyte differentiation. J Neurobiol 49:62-78. CrossRef Medline

Wong WT, Wong RO (2000) Rapid dendritic movements during synapse formation and rearrangement. Curr Opin Neurobiol 10:118-124. CrossRef Medline

Wu GY, Zou DJ, Rajan I, Cline H (1999) Dendritic dynamics in vivo change during neuronal maturation. J Neurosci 19:4472-4483. Medline

Yang JT, Rayburn H, Hynes RO (1993) Embryonic mesodermal defects in alpha 5 integrin-deficient mice. Development 119:1093-1105. Medline

Yang YC, Ma YL, Liu WT, Lee EH (2011) Laminin-betal impairs spatial learning through inhibition of ERK/MAPK and SGK1 signaling. Neuropsychopharmacology 36:2571-2586. CrossRef Medline

Zahir FR, Langlois S, Gall K, Eydoux P, Marra MA, Friedman JM (2009) A novel de novo $1.1 \mathrm{Mb}$ duplication of $17 \mathrm{q} 21.33$ associated with cognitive impairment and other anomalies. Am J Med Genet 149A:1257-1262. CrossRef Medline 